\title{
都市中小河川流域規模を対象とした 短時間雨量の特性
}

\author{
谷岡 康 $^{1} \cdot$ 福岡捷二 ${ }^{2} \cdot$ 伊藤繁之 $^{3} \cdot$ 小山幸也 ${ }^{4} \cdot$ 傅 雲飛 $^{1}$ \\ 1 正会員 パシフィックコンサルタンツ（株） 水工部（†163-07 新宿区西新宿 2-7-1） \\ 2 正会員 P h.D 工博 広島大学教授 工学部第四類 建設系 (テ739 東広島市鏡山 1-4-1) \\ ${ }^{3}$ 正会員 （株）クリアス 設計課（干612 京都市伏見区竹田中島町 122-3） \\ ${ }^{4}$ 正会員 東京都 建設局 河川部 計画課長
}

\begin{abstract}
都市域中小河川流域の，適正な治水計画や河川管理，水防活動を行うためには，狭域・短時間雨量の 特性, つまり雨量の移動や消長等の変動傾向や時空間的な分布の特性を把握する必要がある. 本研究で は，東京都において得られた密な地上雨量観測所網のデータをもとに，都市中小河川で浸水被害を引き 起こしている, 局地的な集中度の高い雷雨と, 比較的広域的な, 継続時間の長い台風による豪雨につい て $23 \mathrm{~km}$ 四方内の 5 分 30 分程度の短時間雨量を対象に雨域の移動や消長, 面積的な広がりの特性を検 討した. さらに，これらの特性から短時間雨量の予測の可能性と雨量観測方法について考察を加えた.
\end{abstract}

Key Words : spatial-temporal characteristics of rainfall, short-time rainfall in small catchment, small river basin in urban area, rainfall forecast

\section{1. 序 論}

都市中小河川流域では, 市街化により地表面がコ ンクリートやアスファルト等による被覆が進み, そ の流出は速く, 流出量は大きくなっている.また, 下水道の雨水排水施設の整備により, 雨水の集中が 速くなってきたことや, 河道自体も, 沿川用地の高 度利用により十分な河幅の確保が困難となり, 狭く 深いコンクリート等で護岸されることが多く, 洪水 の流下や集中の速さを助長している.このような都 市中小河川1) では, 集中豪雨によるいわゆる「都市 型水害」によって毎年のように浸水被害を被ってい る. 現在, 市街化の進んだ都市域の中小河川では, 流出実態に即した治水計画, 洪水調節施設等の適正 な管理, 迅速・確実な水防活動等が必要であり, こ のためには狭い範囲での短時間雨量の変動や分布 の特性, それに伴う洪水流出特性の解明が望まれて いる. 本研究は, 東京都において時空間的に密に得 られた地上雨量計による雨量データをもとに, 都市 中小河川の流出実態を解明することを念頭におき, まず狭域, 短時間雨量の変動や分布の特性を明らか にすることを目的としている.

一般に，都市中小河川では，水文資料が密に得ら
れなかったこともあり, 地域の代表とする地点雨量 の統計処理に基づいた確率雨量を設定し，合理式を 用いて治水計画がたてられる場合が多い1),2).この 対象流域は，おおむね 100～200 $\mathrm{km}^{2}$ ，到達時間 2 時 間程度までの河川とされており ${ }^{3)}$ 降雨の変動や分布 の特性まで考慮されることは少ない.しかし，都市 中小河川の流出実態は, 極めて狭い範囲の短時間雨 量の変動に影響されるところが大きい.

降雨の特性については, 研究が数多くなされ，実 績が積み重ねられている. 建設省土木研究所 ${ }^{4)}$ では, 関東南部を対象に $1 \sim 48$ 時間， $1500 \mathrm{~km}^{2}$ を対象とし た降雨分布の解析を行いそのDADについて明ら かにしている. 吉野ら ${ }^{5), 6)}$ は, レーダ雨量計データ を用いて雨量の時空間的な相関とDADについて 検討している.これらは広域雨量の静的な分布特性, 統計的特性を扱っており，狭域雨量の移動や消長の 変動特性までは述べていない，渡邊ら ${ }^{7)}$ は，広域的 なレーダ雨量の特性に関してその空間的な雨量の 極大点の追跡等を行い, 移動の方向や速度について の統計的分布特性を調べるとともに，雨量の階層的 構造について述べている.このようにレーダを用い た降雨特性の研究が進められる一方で, レーダ雨量 に関しては，地上雨量を用いたキャリブレーション 
表-1 研究対象と寸る短時間・狭域雨量の特性

\begin{tabular}{|c|c|c|}
\hline 対象の雨量特性 & 空間的 & 時間的 \\
\hline 変動特性 & 雨域の移動や & 雨域の消長 \\
& 変形 & (発達・減衰) \\
\hline 分布特性 & $\begin{array}{r}\text { 空間的な集中度 } \\
\text { と分布形状 }\end{array}$ & $\begin{array}{r}\text { 時間的な集中度 } \\
\text { と雨量波形 }\end{array}$ \\
\hline
\end{tabular}

手法やその観測精度についての研究 ${ }^{8)-11)}$ が進めら れている段階である. 狭小域の短時間雨量について は, 河村ら ${ }^{12)}$ がスウェーデンのルンド市について約 $25 \mathrm{Km}^{2}$ の範囲で 1 分雨量の移動方向や時空間的な雨 量の統計的特性を扱っており，1 分先の降雨予測に ついて検討している. 沖ら ${ }^{13)}$ は, 雨滴粒径分布観 測を行い, 観測地点での短時間雨量の時間的変動特 性, 集中度や周期性について興味深い結論を得てい る. 友杉 ${ }^{14)}$ は長崎における集中豪雨の事例について 雨量分布面の起伏形態の特性と面積雨量の推算値 における可能誤差の特性について検討しており,よ り系統的かつ詳細な事例研究を進める必要がある と述べている. 近年では, 中津川ら ${ }^{15)}$ や山田ら ${ }^{16), 17)}$ が, 地上雨量とレーダ雨量を合わせた解析および気 象力学的解析による山地部の地形性降雨特性, 特に 標高による降雨強度の変化について検討している. これらの研究の目的は様々であるが概して短時間 雨量の確率的・統計的特性や静的な降雨量の分布特 性を扱っており，地上雨量をもとにした，都市中小 河川流域規模での, 短時間雨量のダイナミックな時 空間変動特性や分布特性を明らかにする段階まで 至っていない.

本研究では, 都市中小河川の洪水流出現象に直接 結びつくと考えられる, 短時間 (5 分〜30 分程度), 狭域 $\left(10 \sim 100 \mathrm{~km}^{2}\right.$ オーダ) の雨量について, 表一1 に示す空間的・時間的な変動や分布の特性を明らか にする.さらに，その変動特性から降雨の短時間予 測の可能性につき検討を行い, 都市中小河川流域に おける雨量観測方法と予測の可能性についての考 察を加えている. 検討は都市中小河川の浸水被害の 主要因が, 台風のみでなく雷雨であることも多いこ とを考慮し，これらの短時間雨量について比較した。 都市中小河川の流出は極めて小さい時空間スケー ルの雨量に起因すること, 都市域は一般に, 低平地 に位置すること等から，ここでは，地形の影響に大 きく支配される降雨特性や, 大きい時空間スケール での降雨特性は対象としていない.

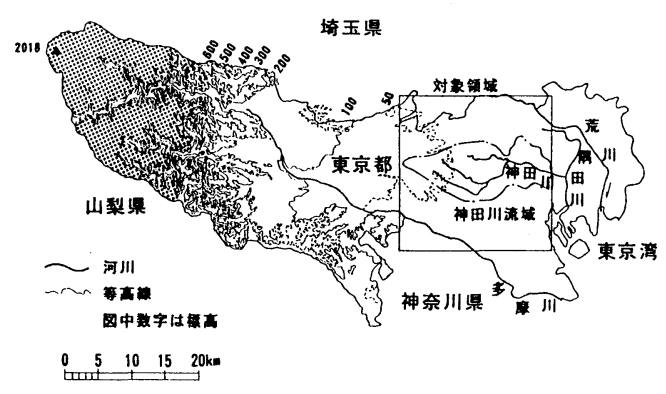

図-1 対象位置

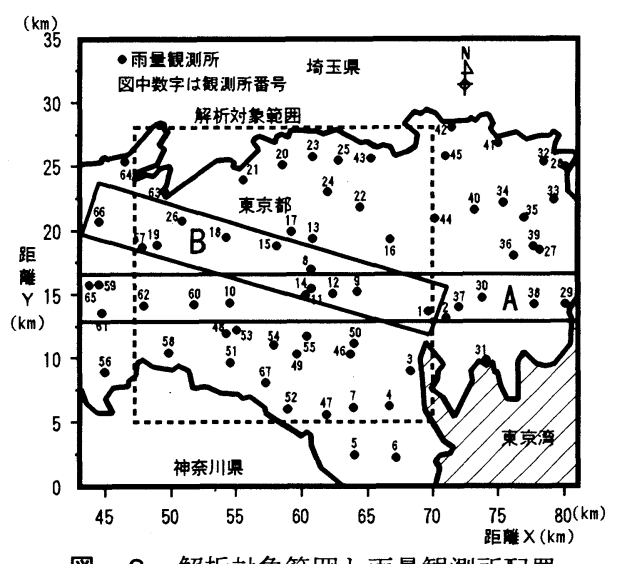

図-2 解析対象範囲と雨量観測所配置

\section{2. 研究の対象}

\section{（1）対象位置・範囲}

研究の対象としたのは, 図一 1 に示す東京都の東 部低地である. 地形はおよそ平坦で, 雨量データが 密に得られた，23km四方 (約 $530 \mathrm{~km}^{2}$ ) を解析の対 象としている. 雨量観測所は, 平均的に $3 \sim 5 \mathrm{~km}$ に 1 ヶ所程度で配置されている（図一2）。対象領 域には東京都中心部を貫流する代表的な中小河川 である神田川流域 ${ }^{1)}$ (流域面積 $105 \mathrm{~km}^{2}$ ) が含まれて いる.

\section{（2）対象降雨}

対象とした降雨は, 雨量データが密に得られて いる近年のデータで, 対象領域に比較的規模の大き い雨量を記録した台風と雷雨である（表一2）。降 雨規模は地域的には降雨強度 $50 \mathrm{~mm} / \mathrm{hr}$ を超え, 本邦 の中小河川の当面の整備目標である「時間 50 ミリ 相当に対処出来る安全度:整備率 $38 \%$ (1993 時点) $]^{[18)}$ に比べて大きく, 都市中小河川の洪水流出を対象 


\section{表 -2 対象降雨}

\begin{tabular}{|c|c|c|c|}
\hline \multicolumn{2}{|c|}{ 降雨要因 } & 年.月.日 & 10 分間 \\
\hline \multirow[t]{4}{*}{ 台 風 } & 12 号 & 1991. 8. 20 & $90 \mathrm{~mm} / \mathrm{hr}$ \\
\hline & 18 号 & 1991. 9. 19 & $72 \mathrm{~mm} / \mathrm{hr}$ \\
\hline & 4 号 & 1993. 7.25 & $72 \mathrm{~mm} / \mathrm{hr}$ \\
\hline & 11 号 & 1993. 8.27 & $78 \mathrm{~mm} / \mathrm{hr}$ \\
\hline \multirow{3}{*}{\multicolumn{2}{|c|}{ 雷 雨 }} & 1994. 7. 7 & $120 \mathrm{~mm} / \mathrm{hr}$ \\
\hline & & 1994. 7.18 & $132 \mathrm{~mm} / \mathrm{hr}$ \\
\hline & & 1994. 9. 2 & $102 \mathrm{~mm} / \mathrm{hr}$ \\
\hline
\end{tabular}

（ピーク雨量は領域内最大観測値）

1993.8.27 12:20 台国
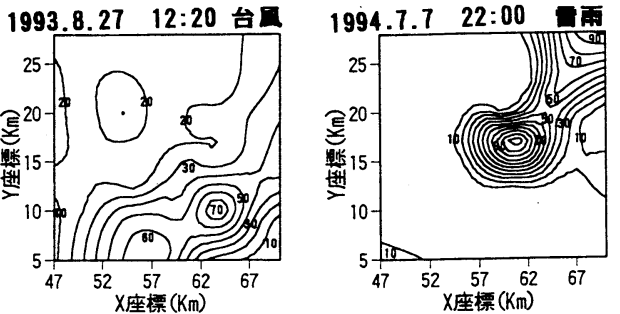

(a) 空間分布 (コンターは $10 \mathrm{~mm} / \mathrm{hr}$ 間隔)
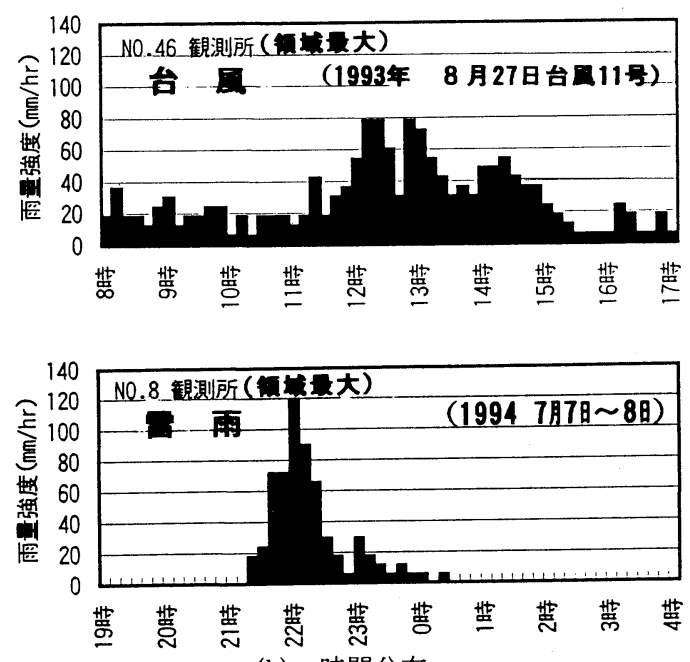

(b) 時間分布

図－３雷雨と台風の雨量分布（10 分雨量）

とする場合には，遜色のない規模である．台風につ いては 10 分, 雷雨に関しては 1 分毎の地上雨量 $(1 \mathrm{~mm}$ 単位) が得られている. 図一 3 に台風及び雷雨の分 布を示す. 台風に比べ, 雷雨は空間的, 時間的に集 中度が極めて高いことがわかる.

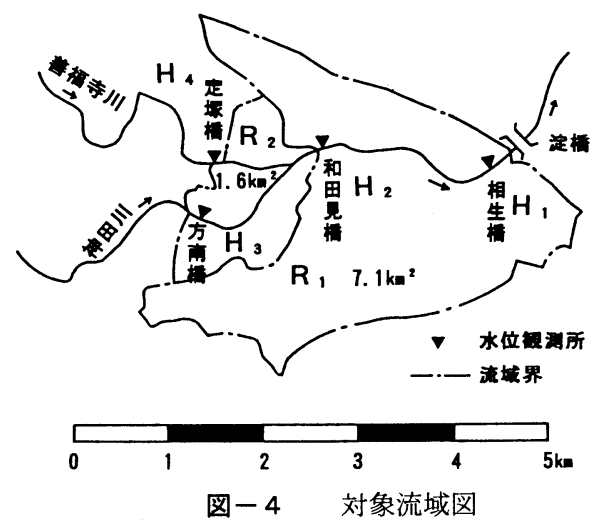

\section{3. 短時間雨量の取り扱い}

\section{（1） 雨量と水位の直接的関係 ${ }^{19)}$}

本研究で降雨の特性を明らかにする目的は，最終 的に, 都市中小河川の流出現象に対応させることで ある. 著者らは, 都市中小河川の洪水時の河川水位 が狭小域・短時間の流域平均雨量 (30 分平均雨量) と流量一水位の関係式を介さずとも, 極めて直接的 な関係であり単純な線型式で再現出来ることを示 した. 対象とした神田川は, 東京都内の区部を流れ る中小河川では最大の流域面積をもつ ${ }^{1)}$ 代表的な都 市中小河川である. 沿川流域は市街化が進み, 下水 道施設もほぼ整備されており, 流域の 9 割が市街化 されている.

本研究では, 図一 4 に示す神田川中流部の支川善 福寺川合流前後の延長約 $3.8 \mathrm{~km}$ の区間とその間に流 入する流域 $8.7 \mathrm{~km}^{2}$ を対象としている.ここで淀橋直 上流相生橋 $\left(\mathrm{H}_{1}\right)$, 神田川・善福寺川合流直後の和 田見橋 $\left(\mathrm{H}_{2}\right)$, 合流点上流の神田川方南橋 $\left(\mathrm{H}_{3}\right)$, 善 福寺川定塚橋 $\left(\mathrm{H}_{4}\right)$ 地点の水位及び，各水位計間の 残流域雨量 $\mathrm{R}_{1}$ (相生橋 和田見橋)， $\mathrm{R}_{2}$ (和田見橋 ～方南・定塚橋)を用い，洪水位と雨量の直接的関 係を検討した．対象区間の上流には，29. $0 \mathrm{~km}^{2}$ と残 流域（約 $8.7 \mathrm{~km}^{2}$ ）の約 3 倍の流域をもっている.

流域の平均雨量は, 小流域の降雨分布を細かに反 映するために，対象流域に 500m の格子を作成し， 雨量観測所の 10 分毎のデータに基づき, 各格子点 と観測所の距離による重みで荷重平均した值を, 流 域で平均することで求めた ${ }^{20)}$. 又, 残流域の到達時 間は下水道諸元等から約 30 分と推定されるため, 10 分雨量をもとに 30 分間の雨量の移動平均值を各 時刻の流域平均雨量として扱った。 
上流 2 地点の水位 $\left(\mathrm{H}_{3}, \mathrm{H}_{4}\right)$, 残流域雨量 $\left(\mathrm{R}_{1}\right.$, $\left.\mathrm{R}_{2}\right)$ 及び下流の水位 $\left(\mathrm{H}_{1}\right)$ の実績值から, これらの 線形関係を前提に求めることにより次式が導かれ $る^{19)}$.

$$
\begin{aligned}
& \mathrm{H}_{1}(20)=0.532 \mathrm{H}_{3}(0)+0.639 \mathrm{H}_{4}(0) \\
& +0.135 \mathrm{R}_{1}(20)+0.046 \mathrm{R}_{2}(10)-35.956
\end{aligned}
$$

ここに（）内は，0 を現時刻として，10，20 は 10 分後, 20 分後の值を示し, 河道の流下時間を考 虑したものである. 図一 5 にこの水位一雨量関係式 (1)により，上流 2 地点水位 $\left(H_{3}, H_{4}\right)$ と残流域 雨量 $\left(R_{1}, R_{2}\right)$ を用いて計算した下流点水位 $H_{1}$ と, その実績水位の比較を示す. 台風のみならず局地性 の高い雷雨による洪水においても，計算された水位 の実績水位に対する標準偏差は, 水深約 $4 \mathrm{~m}$ の $3 \%$ である $10 \mathrm{~cm}$ 程度であり, 良好に再現出来ている. 図一 5 の点線は式(1)において残流域雨量 $\left(R_{1}, R_{2}\right)$ を0とした場合の，下流水位に対する上流水位の影 響分を示す.上流水位の影響分は, 下流水位のうち, ピーク時で約 40〜80\%であり，特に図ー5（a）に 示す雷雨時には約 $40 \%$ と小さい. 逆にピーク時の下 流水位は, 上流 $29.0 \mathrm{~km}^{2}$ から流れてくる水位の影響 より, 残流域 $8.7 \mathrm{~km}^{2}$ (約 $30 \%$ の面積) の流出分が水 深の $60 \%$ 以上も支配する場合がある.これらから， 残流域の流出形態は降雨波形と強い線形的関係に あり，流出波形は小流域の 30 分平均雨量に即応す る速い流出に大きく影響されていることがわかる. 著者ら ${ }^{20), 21)}$ は，都市中小河川流域規模における雨 量観測所の密度と面積雨量精度について検討して いるが, 対象としている東京都の雨量観測所密度で の面積雨量の計算值は, この水位の良好な再現性か らみても十分な精度であるといえる.

都市中小河川における流出は, 狭い範囲 $\left(10 \mathrm{~km}^{2}\right.$ 以下）での 30 分程度の平均雨量と直接的関係にあ り，その影響が大きく，この時空間スケールでの降 雨量を精度よく把握することと，その降雨特性を明 らかにすることが重要であることがわかる.

\section{（2）対象雨量の時空間的なスケールと取り扱い}

都市中小河川の降雨と流出との直接的関係から, その流出実態を解明するには, 流域規模 $\left(1 \sim 10 \mathrm{~km}^{2}\right.$ 単位) や流域の到達時間 (10 30 分程度)に対応する スケールの雨量特性を明らかにすることが必要で
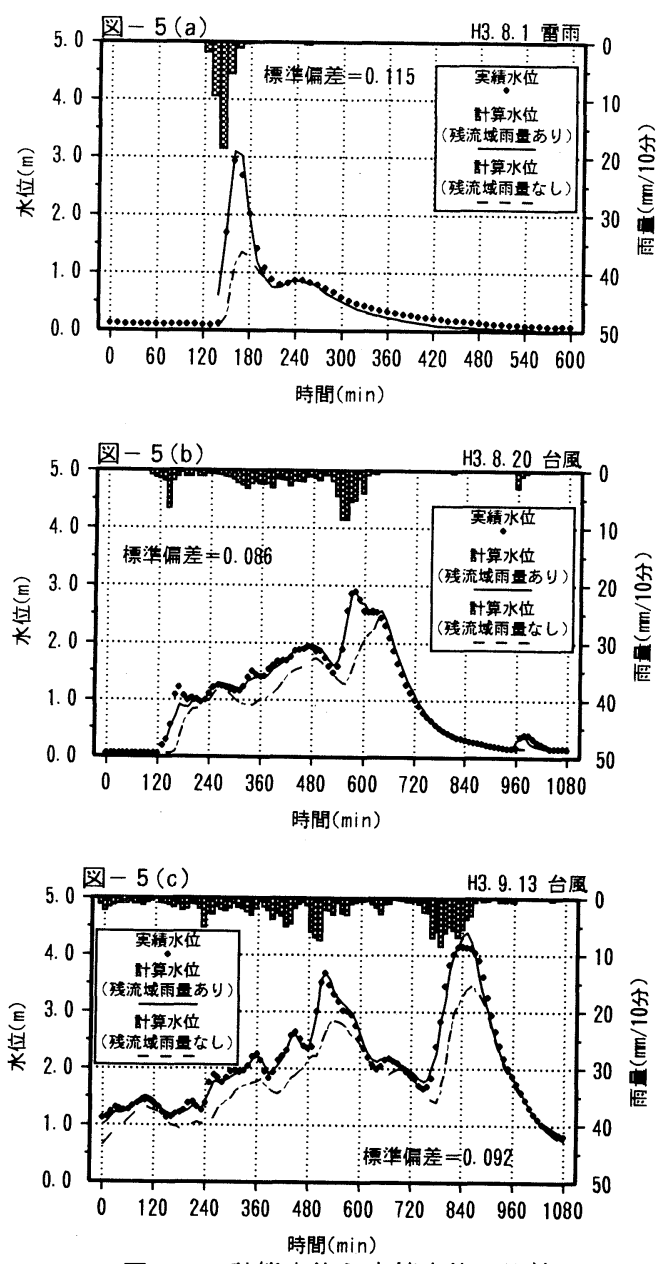

図一 5 計算水位と実績水位の比較

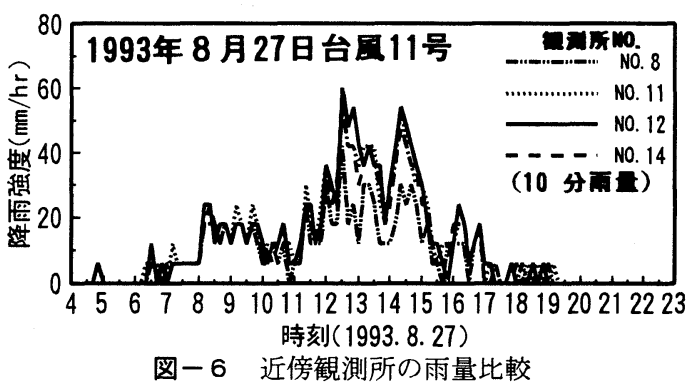

ある.この時空間スケールは，いわゆる積雲対流規 模の現象であり，メソ $\gamma$ （数 $\mathrm{km} \sim$ 数十 $\mathrm{km}$ ，数分〜 数時間) ${ }^{22)}$ といわれるスケールの気象現象と考えら れる. 本研究で用いる雨量データは，1 分あるい は 10 分毎の平均 $3 \sim 5 \mathrm{~km}$ 間隔に配置された転倒ま す（1mn 計）による地上雨量であり，時間的には累 積雨量 (5 分, 10 分) を扱う。このため, 対象とし た地上雨量は, 瞬時瞬時のエコー強度を雨量に換算 


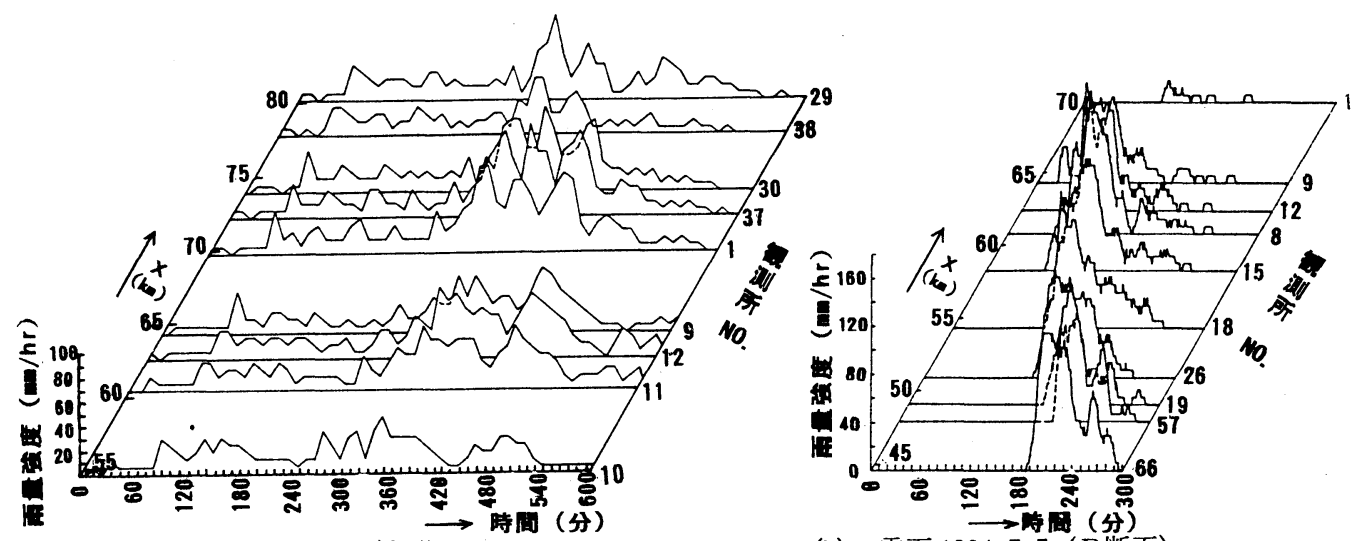

(a) 台風 1993.8.27 (A 断面)

(b) 雷雨 1994.7.7 (B断面)

図-7 雨量の時空間的変動

するレーダ雨量とは, 本質的に異なる. また, 前述 の様に都市中小河川の流出との直接的関係も極め て強い. 図-6は近傍観測所の 10 分雨量値の連続 性を調べたものである. 約 $3 \mathrm{~km}$ の範囲に入る近傍 の観測所 4 力所の雨量は, 時間的に細かい振動はし ているものの同様の増減傾向を示し, 空間的な相関 は強く, 観測点間でのランダムな変動は見られない. 図ー7は観測所の配置と強雨を記録した位置を参 照し，図一2に示すA，Bの直線断面を設定して雨 量の時空間的な変動を調べたものである. 離れた観 測所においては別の波形となるが, 近い観測所では, 各々関連した連続的な変動を示している. 以上から 雨量データの変動や分布は, 本研究で対象としてい る現象のスケールでは, 時空間的に連続していると 考えられ，この前提のもとで，降雨特性を明らかに する.

\section{4. 台風の時空間変動特性}

\section{（1）台風による雨量の変動状況 ${ }^{23)}$}

対象とした台風のうち最も規模の大きかった 1993 年 8 月 27 日台風 11 号を対象に, 雨量の変動 状況を調べた。短時間雨量の, 空間的な関連性を調 べるために, 図一2に示す A 断面を用いて時間的な 雨量分布と, 観測所の位置の関係を調べ, 横軸に時 間, 縦軸に雨量, 斜軸に距離として図化したのが図 ー8である.ここで降雨量は 10 分雨量記録をもと に 10 分毎に 30 分間で移動平均した量を対象として いる. 30 分平均雨量を用いたのは, 前述の様に対
象とした都市中小河川での水位の応答性が良好で あったことによる. 各観測所の雨量は, 雨雲ひとつ ひとつの発生減衰サイクルに対応しているものと 考えられる $40^{13)} \sim 60$ 分程度の振動がみられる. 図 より明らかなように, $20 \mathrm{~km}$ 程度の範囲では降雨の 山・谷の位置的な変動や時間的な移相を連続的に読 みとることが可能である.ここで各地点での雨量の 時間的な山や谷の発生時刻とその雨量を抽出し, 位 置的・時間的な変動を調べた。図ー10，図ー11は 領域のほぼ中心に位置する No. 11 観測所の雨量波 形から, 近傍観測所と関連が見られる降雨波形の山 や谷の変曲点 $a \sim j$ を設定し (図一9），A断面内 の各観測所でそれに相当する山・谷の発生時刻とそ のときの雨量強度を抽出し示したものである. 図一 10 では, 横軸に観測所の位置による距離, 縦軸に 雨量強度を示す. バラツキがあるものの, 発生時刻 の異なる山々が $70 \mathrm{~km}$ (東) 付近で最大となり $45 \mathrm{~km}$

(西)に向かってゆるやかに減衰していく傾向があ る. $20 \mathrm{~mm} / \mathrm{hr}$ 程度の小さい雨量の場合は, 位置的に 変動が小さい. 対象とした台風では, A 断面の方向 と雨域の実際の移動方向とは, 必ずしも一致はしな いが，降雨波形の山の消長は位置的にゆるやかで あると考えられる． $71 \mathrm{~km}, 78 \mathrm{~km}$ 等の地点で他地点 に比べ一様に小さい值を示す傾向が見られるのは, 近傍のビル等障害物の影響や局所的な風による地 上雨量計の捕捉量に対する影響, 地形的な影響, 観 測機器の性能及び故障等が考えられる. 一方, 図一 11 に示す降雨量の山と谷の位置的な発生時刻をみ ると，西へいく程遅い傾向にあり,およそ一定にゆ 


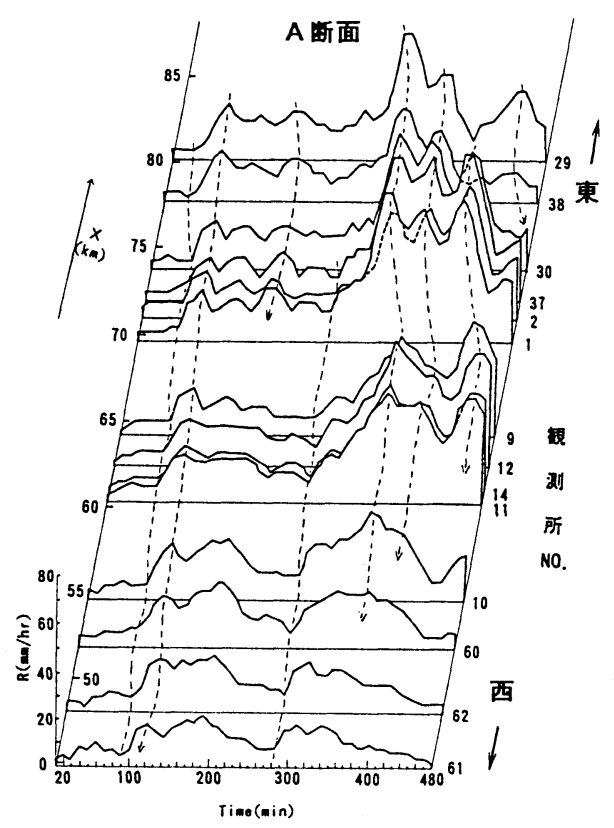

図-8 雨量波形の変動

るやかに傾いている.

降雨波形が近隣観測所同士では類似しており,位 置的にも時間的にも連続的に変形していることから， 各観測所間の降雨波形の時間的なずれが雨域の移 動によるものと考えることができる. 雨域の移動特 性を調べるために, 解析対象範囲のほぼ中央に位置 する, No. 11 の観測所を中心として, 周辺観測所と の間で 10 分単位 (観測值が 10 分単位で得られてい るため)で波形をずらしたときの雨量波形の相関を とり，最も相関係数の高い移相時間を調べた。この ようにして得られた值の面的な分布を示したもの が図-12 である. 対象領域内では，移相時間の分 布はほぼ南東方向へ平面的に傾いていることがわ かる.このことより, 対象範囲内では, 比較的一様 な移動をしていると考えられる.さらに相関係数は， 移相時間 0 分〜 +40 分までの雨量の大きい範囲で 0.9 以上と高い. 雨域は中心へ向かって北西方向人 移動しており, 中心付近を過ぎると, 減衰してゆく ために雨量が小さくなり, 明確な相関関係が薄れて ゆくと推定出来る. 中心点より $10 \mathrm{~km}$ 程度離れた南 東部の観測点でも 20〜 40 分の移相時間で相関が高 く,降雨波形の強い関連性とその移動による時間の ずれが空間的に一様に傾斜している様子がわかる.

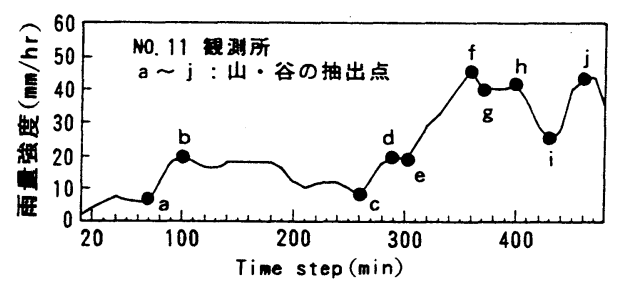

図-9 雨量の山・谷の抽出

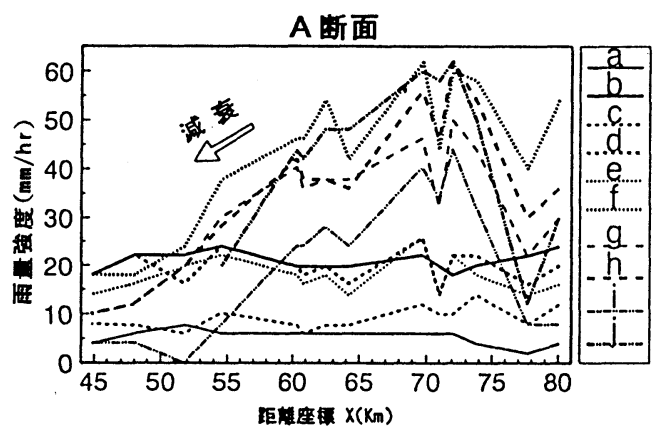

図-10 降雨波形の山・谷の位置と大きさ

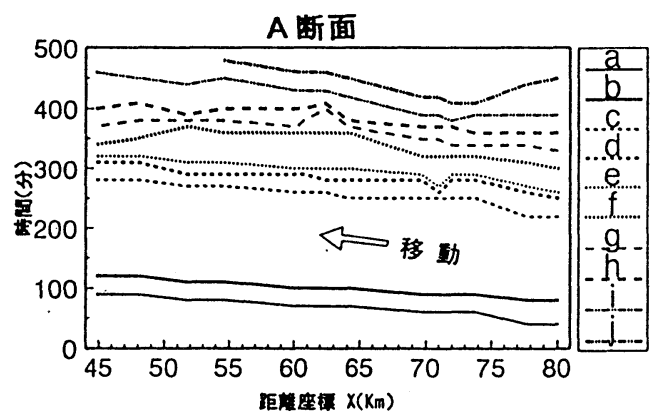

図-11 降雨波形の山・谷の位置と発生時刻

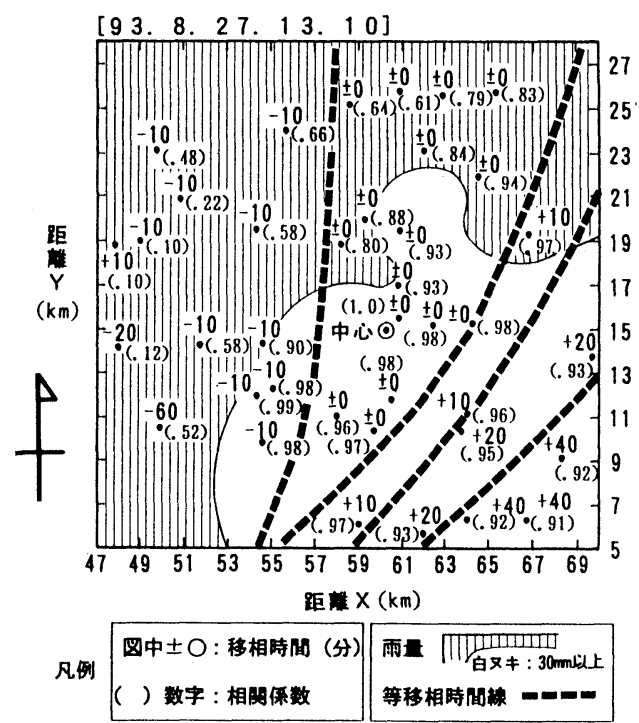

図-12 降雨波形の移相時間と相関係数の平面分布 


\section{（2）雨域の移動と消長の計算方法 ${ }^{23)-25)}$}

雨量分布の 10 分毎の経時変化を調べ，その移動 方向の断面について雨量の時間的な変動を示した ものを図ー13 に示す. 雨量分布を 10 分毎でみると， その前後で関連して移動, 消長している様子がみれ る.ただし，対象とした $23 \mathrm{~km}$ 四方の中では雨域の 一部が観測されるのみで, その全容は把握出来ない. つまり, 対象領域内に雨域のピークを含む時間帯に おいては，およその移動が観れても，ピークを含ま ない時刻においては, 移動による変動か, 消長によ るものかを識別出来ない. 雨域の移動や消長量を求 める方法は, 降雨の運動学的予測手法である雨域追 跡法 ${ }^{26)}$ や移流モデル ${ }^{27)}$ 等にみられる時刻の違う 2 つの雨域の空間分布の相関関係から求める方法 がある. 本研究での対象範囲が台風のひとつの雨域 を抱絡する広さでないため,この方法によることは 困難である.このため, 対象領域内の雨量観測值の 移相時間毎の波形相関をとり, その相関の高い移相 時間の空間分布を作成し,移動の方向と速さを求め ることとした.

雨域の移動と消長を求める方法 ${ }^{23)-25)}$ の概略を図 -14 の (a)〜 (d) に示す.

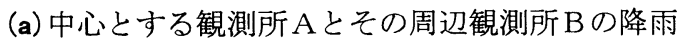
波形について移相時間 $\Delta \mathrm{t}$ による相関をとり,最も 相関の高い $\Delta \mathrm{t}$ を観測所毎に求める. (b)この $\Delta \mathrm{t}$ の空間分布から Aを中心として平面回帰を行う。こ の平面回帰面の傾きの方向と角度 $(\Delta \mathrm{t} / \Delta \mathrm{L})$ か ら速度ベクトルを求め, Aにおける移動べクトルと する. (c) 同様に領域内の全ての観測所を中心とし て,その中心観測所における移動べクトルを求める. このベクトルの $\mathrm{u}, \mathrm{v}$ を変分法により空間内挿し, 移 動ベクトルの平面分布を作成する.この移動ベクト ルの方向は, 降雨分布の経時変化と良く一致するが, 移動量は, 移相時間が 10 分単位と粗いために, 実 際と合わない場合がある.このため移動量の精度を 向上させるために, 求めた移動方向を固定し, 移動

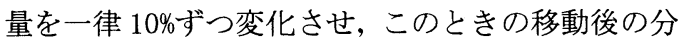
布と, 雨量の実測值との空間相関が最も高い移動量 を求める. (d) 消長量は前時刻ステップからの移動 のみの雨量分布と, 実測値による雨量分布との差と して計算する. 消長量は, 対象領域内で一律でなく 空間分布を与えるものとし, 各観測点の消長量を変 分法により空間内挿する. 観測点間の雨量波形の相 関は，短時間雨量の周期性（60〜120 分程度）とデ
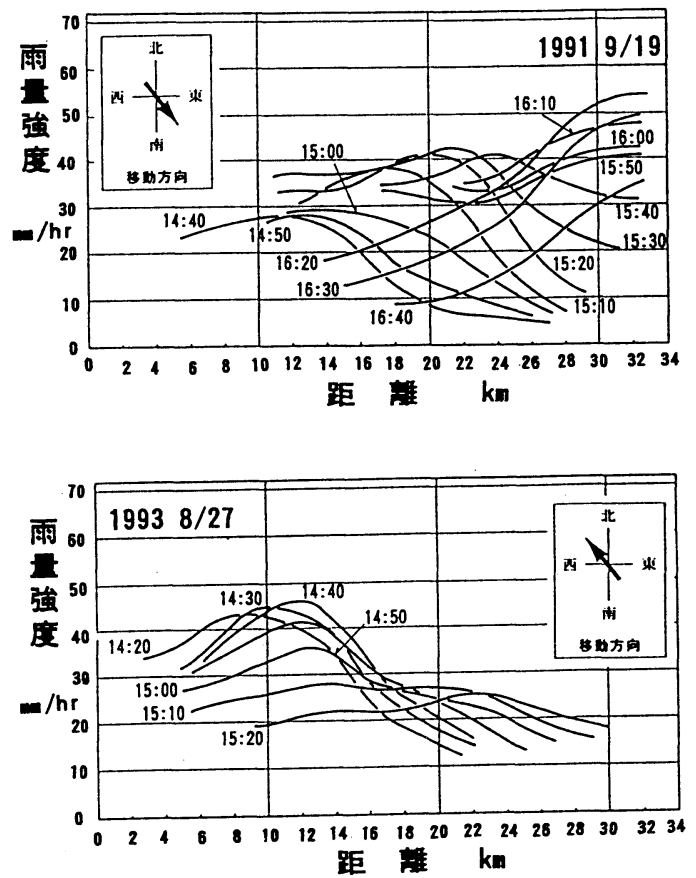

図－13 台風による雨量断面の経時変化

(a)
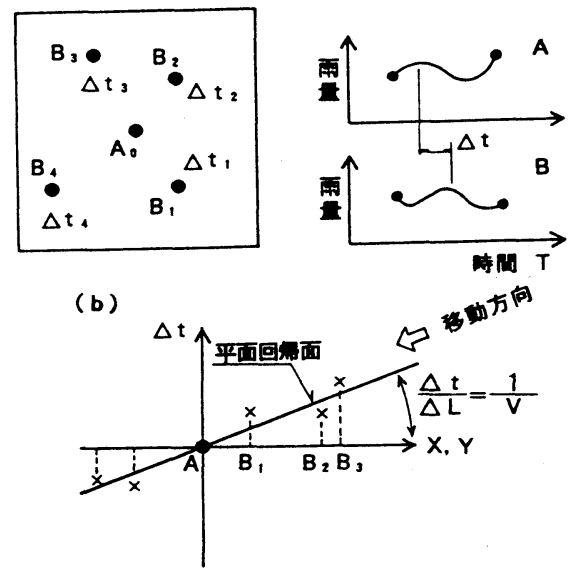

(c)

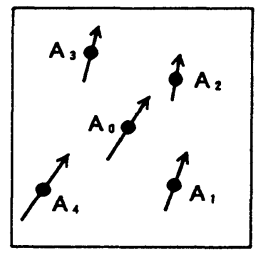

(d)

図-14 雨域の移動と消長の計算方法の概念図

一夕数（10 分毎）を考慮し，対象時刻の前後 60 分 の範囲の雨量波形を対象とし, 時々刻々 (10 分毎) に計算している. 
本研究においては, ランダムに配置されている観 測所の雨量值や移動速度等をもとに対象領域内に 設定した $1 \mathrm{~km}$ の格子点に空間的な内挿を行ってい る. 内挿の方法は, 検討事例 ${ }^{28)}{ }^{29)}$ のある変分法を用 いた。この方法は実測值を $f(x, y)$, 内挿值を $f_{c}(x, y)$ としたとき, 次式 (2) を最小にする $f_{c}(x, y)$ を求めるものである.

$$
\iint\left\{\alpha\left(f_{c}-f\right)^{2}+\beta\left[\left(\frac{\partial f_{c}}{\partial x}\right)^{2}+\left(\frac{\partial f_{c}}{\partial y}\right)^{2}\right]\right\} d x d y
$$

ここで $\alpha, \beta$ は，観測值との整合性と観測所間にお ける雨量の分布が不自然な值とならないことを確 認し， $\alpha: \beta=32: 1$ を用いている.

\section{（3）台風による雨量の時空間的変動特性}

対象とした図-15 に示す 4 つの台風の中で図中 に示す強雨を記録した時間帯を 3 時間毎に 6 波形 抽出し, 各々の雨域の移動と消長等の変動特性につ いて調べた。（表一3 参照）

6 波形の雨量分布の 10 分毎の経時変化と計算さ れた移動ベクトルの分布を図ー16 に示す. 図中の 移動ベクトルは, 10 分間での移動距離を示してい る. $30 \mathrm{~mm} / \mathrm{hr}$ 以上の強雨域をハッチで示すが，強雨 域の 10 分間における移動方向・距離と各時刻の移 動ベクトルはほぼ一致しており, 雨域の移動の方向, 速度をよく説明出来ている. 雨域の移動は, 大きい 雨量の範囲ではほぼ一様であり, 時間的にも安定し ている.またその大きさは, 遅い場合と速い場合が あり, およそ $5 \sim 20 \mathrm{~km} / \mathrm{hr}$ 程度であり, ひとつの雨 域内での時空間的な変動は殆どみられない. 移動の 方向は様々であり, 台風の中心の移動方向や地上風 の方向とは必ずしも一致していない. また, 抽出し た降雨では, 西方向 (海から山地部の方向) 一移動 するものは見られなかったものの, 特に地形や海陸 の位置関係による地域的な雨域の移動の方向の特 性はみられないようである.1991.9.19のように同 じ台風の中で 2 波形抽出した場合に, 時刻によって 雨域の移動の方向が大きく変化する場合もある. 同 じ雨域での変形は殆どみられず 30 分程度の範囲で はほぼ同様な分布形状で移動していると考えられ る.
表一3 対象降雨の抽出範囲

\begin{tabular}{|c|c|}
\hline 対象降雨 & 抽出時間 ( 3 時間) \\
\hline 1991.8 .20 & $15: 00 \sim 18: 00$ \\
\hline \multirow{2}{*}{1991.9 .19} & A. $9: 00 \sim 12: 00$ \\
\cline { 2 - 3 } & B. $14: 00 \sim 17: 00$ \\
\hline 1993.7 .25 & $5: 00 \sim 8: 00$ \\
\hline \multirow{2}{*}{1993.8 .27} & A. $11: 00 \sim 14: 00$ \\
\cline { 2 - 2 } & B. $14: 00 \sim 17: 00$ \\
\hline
\end{tabular}

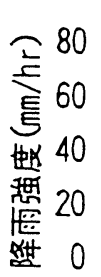

1991.8. 20

\section{地上雨量（NO.11 覤澌所）}

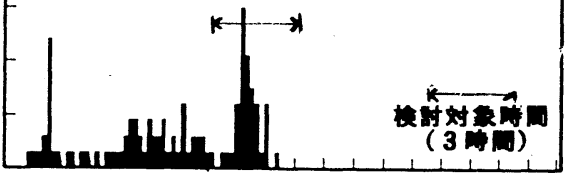

$\begin{array}{lllllll}8 & 10 & 12 & 14 & 16 & 18 & 20\end{array}$

時 刻

1991. 9.19

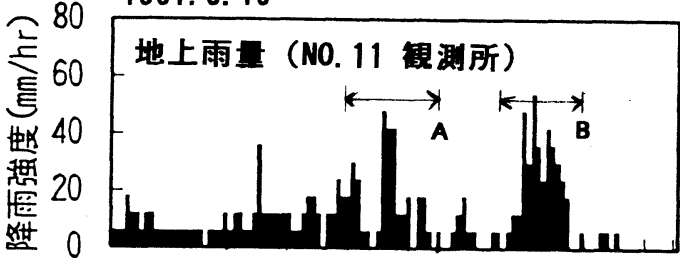

$\begin{array}{llllllllll}1 & 3 & 5 & 7 & 9 & 11 & 13 & 15 & 17 & 19\end{array}$ 時 刻

1993. 7.25

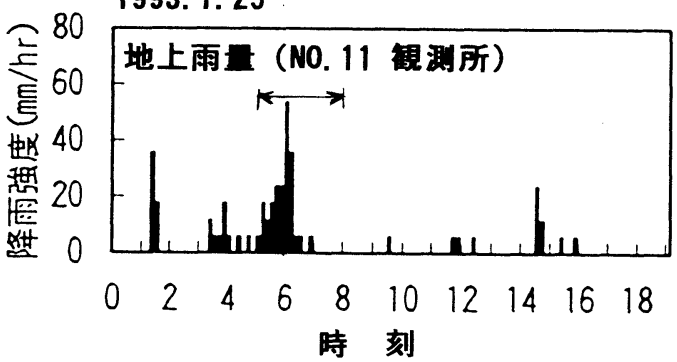

1993. 8. 27

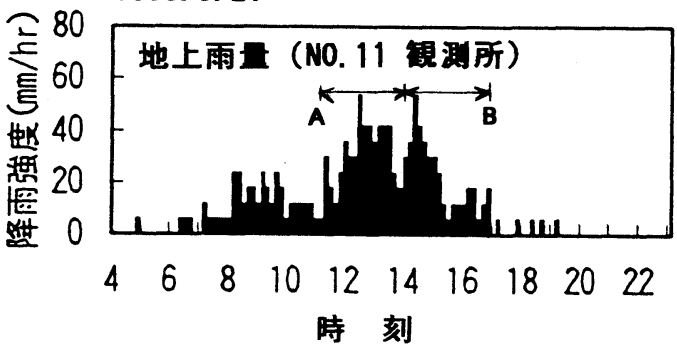

図一15 対象とした $4 つ の$ 台風の降雨波形 

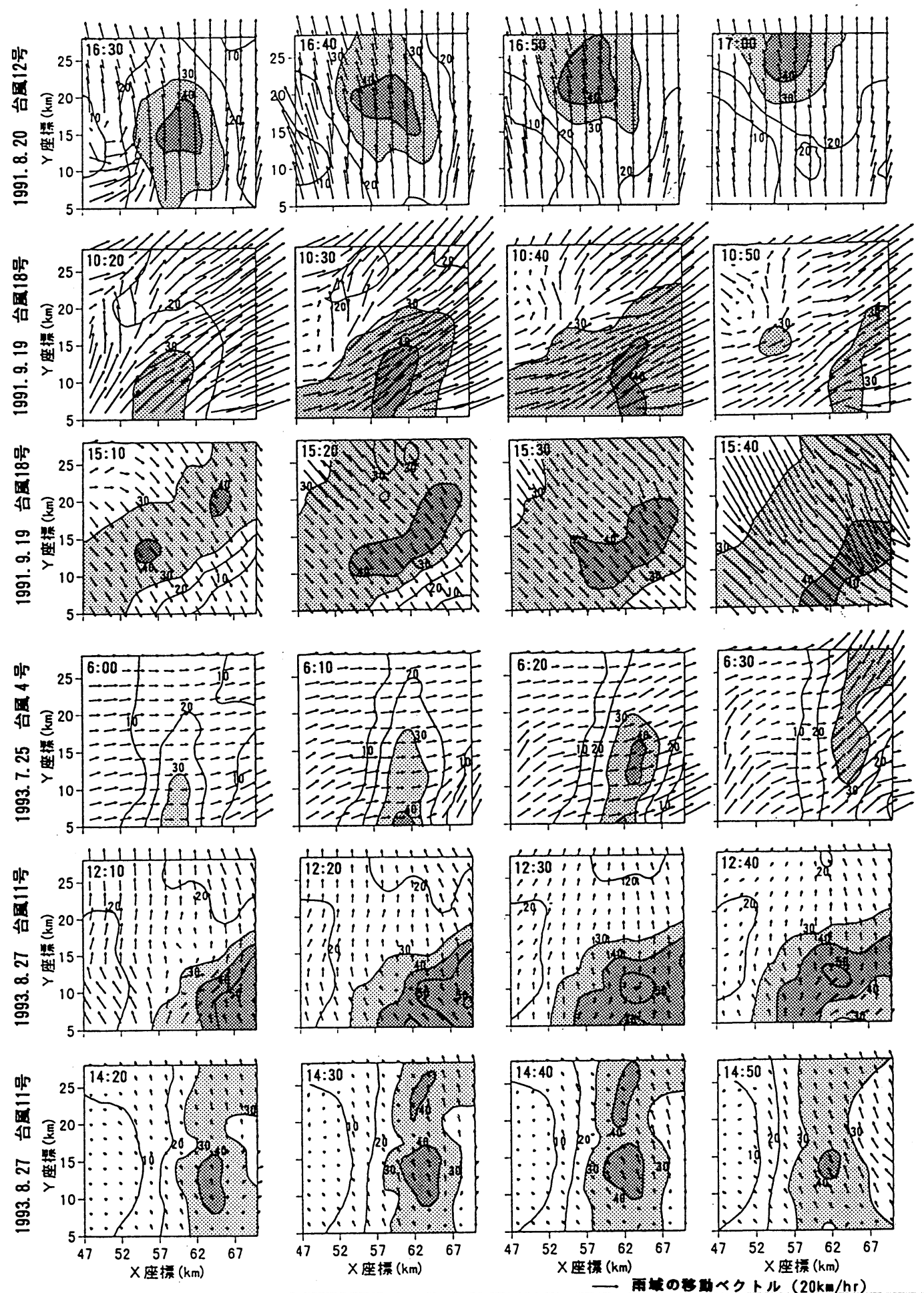

图ー16 台風の雨量分布の経時変化と計算移動ベクトル（コンターは $10 \mathrm{~mm} / \mathrm{hr}$ おき） 

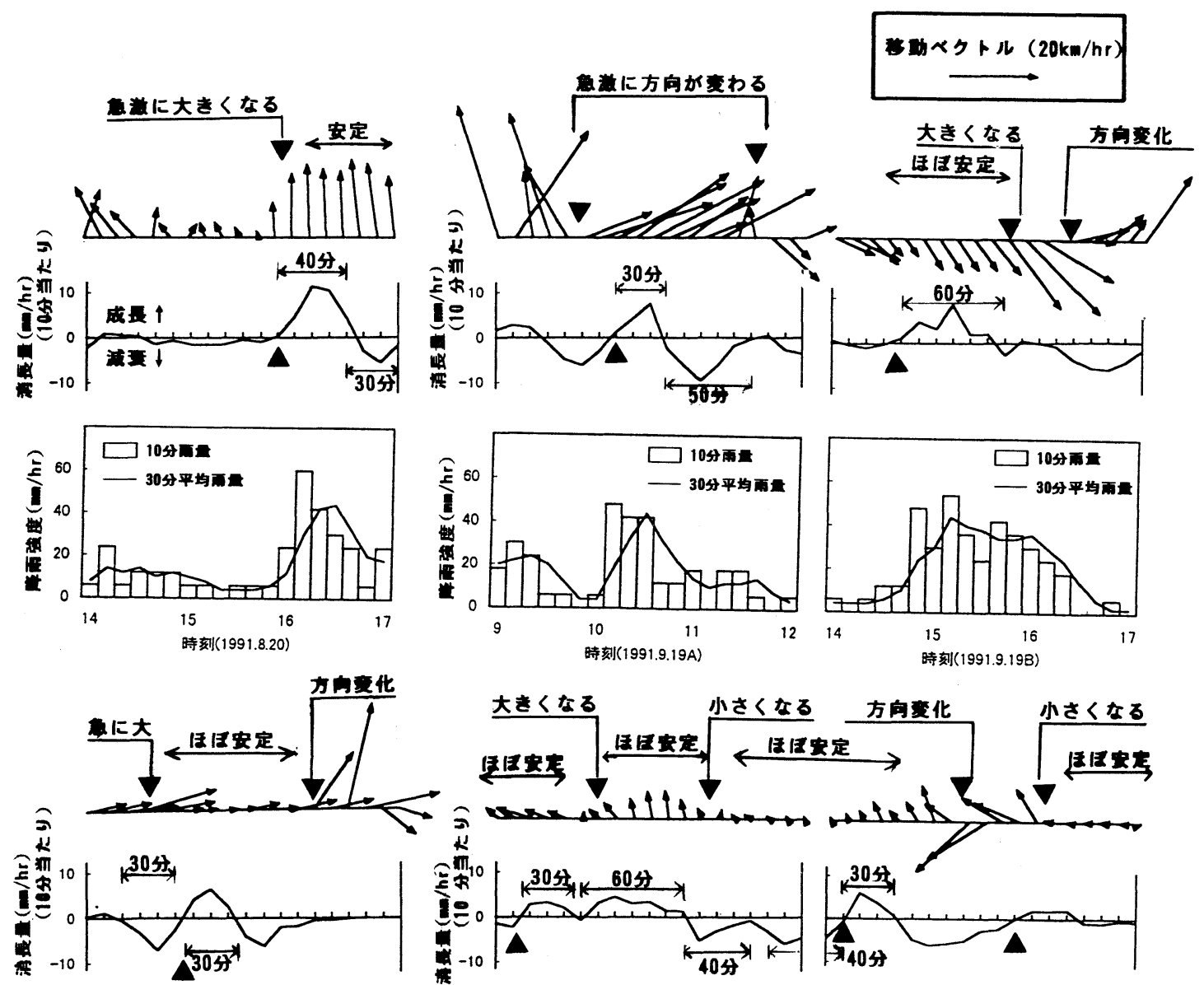

怔ハクトル $(20 \mathrm{~km} / \mathrm{hr})$
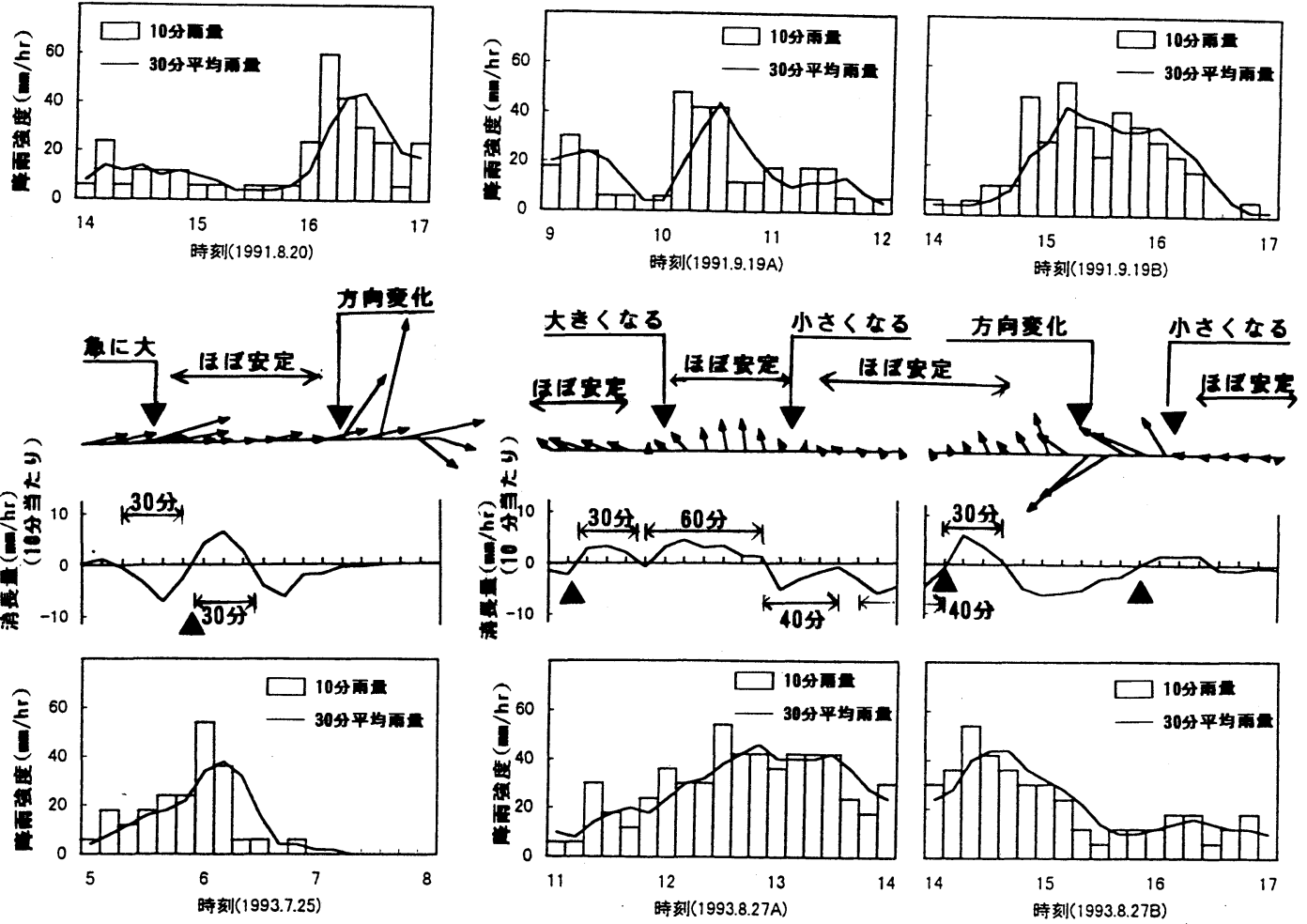

図-17 雨域の移動と消長量

図-17に領域中央付近（N0.11 観測所）における 雨域の移動ベクトル, 消長量, 降雨量の経時変化を 示す. 雨域の移動がほぼ安定し雨量が大きい時間帯 での成長や減衰の各々の継続時間は消長量の図中 に示すように 30 分 60 分程度である. 成長・減衰 による 10 分当たりの消長量は, ピーク $50 \mathrm{~mm} / \mathrm{hr}$ 程度の降雨に対して $5 \sim 10 \mathrm{~mm} / \mathrm{hr}$ であり，10～20\% の変動を示している. 降雨予測を行う場合，この消 長量を正確に見積もらなければ 10 分後でもピーク の $20 \%$ 程度の誤差は避けられないと考えられる. 雨域の移動ベクトルの経時的な変化をみると, 図中
に移動ベクトルの大きさや方向が急激に変化する 時刻にマ印を付しているが, その間の雨量の大きい 範囲ではほぼ安定しており, 雨量の立ち上がり部で 大きく変化する場合が多い. また, 消長量は立ち上 がり部で減衰から成長へ逆転する（図中 $\Delta$ 印）場合 が多い.これらは雨域の対象領域内人の来襲・通過, と個々の雨域の発達・減衰の組合せによる変動と考 えられる.これはこれらの移動, 消長の変動傾向を いかに事前に把握出来るかが, 降雨予測を行う場合 には重要であることを示すものである. 


\section{5. 雷雨の時空間変動特性}

雷雨は時間的な変動が激しいことから, 極めて短 い時間間隔（10 分以内）での雨量データが重要で ある.このため 1994 年に 1 分雨量データの収集が 行なわれた.この年には, 大きな台風の来襲がなく, 雷雨による雨量データのみが得られている.これを 用いて, 雷雨による雨量の変動特性について検討し た.

\section{（1）雷雨の発生状況}

得られた雨量データは, $1 \mathrm{~mm}$ 計の為, 1 分毎では 0 から $3 \mathrm{~mm}$ （降雨強度に換算すると $180 \mathrm{~mm} / \mathrm{hr}$ ）まで の数值が記録されている.これを 1 分毎に 5 分の移 動平均を行い, 短時間雨量強度の変動として扱った. 図-18 は, 1 分毎の空間的な雨量分布の経時変化か ら各々の雨量ピークの時刻を抽出し, $50 \mathrm{~mm} / \mathrm{hr}$ 以上 の強雨を示した範囲の経時変化を調べたものであ る. 局所的に集中した雨量は発生, 発達, 減衰を繰 り返し，その雨域も徐々に移動していく様子 ${ }^{30)}$ が みられる. どの雷雨も初期に発達・減衰した位置の 近傍に $15 \sim 30$ 分程度後に連続して発生している.

(c) 1994.9.2 雷雨では, 西から東へほぼ一様な方向 へ連続して発生しているようにみてとれるが,

(a) 1994.7.7 雷雨のように, ひとつの雨域から 2 方 向に分裂して発生する，あるいは(b) 1994.7.18 の 様に迷走しながら全体として一定方向（北方向）に 移動することもある。これは，二宮 ${ }^{31)} の$ 述べてい る「積雲の近くに次つぎに発生する積雲対流は降水 に伴う下降流 (ダウン・ドラフト) と下層風との収 束による」ことと関連していると考えられる. 雷雨 による地上雨量は 3 例ではあるが, 狭い範囲でみれ ば, 1 ヶ所で発生した位置から次々に連なって発生 している様である.

\section{（2）雷雨の時空間変動特性}

雷雨の移動方向をもとに図一18(a)，(c)に示すC， Dの断面を設定し, その雨量分布の経時変化を示し たものが図ー19，20 である. 断面図は変分法によ る格子点の内挿値をもとに図化している. 図では, 個々の雨量の分布の山に着目し，その成長期を実線， 減衰期を点線で区別し, その周期別に期間を区切っ て, 1 分毎の雨量断面図を示している. 図ー20の 1994.9.2 の雷雨では, 水平方向に約 $10 \mathrm{~km}$ の広がり をもつ雨量が発達・減衰をくりかえし, その発生位
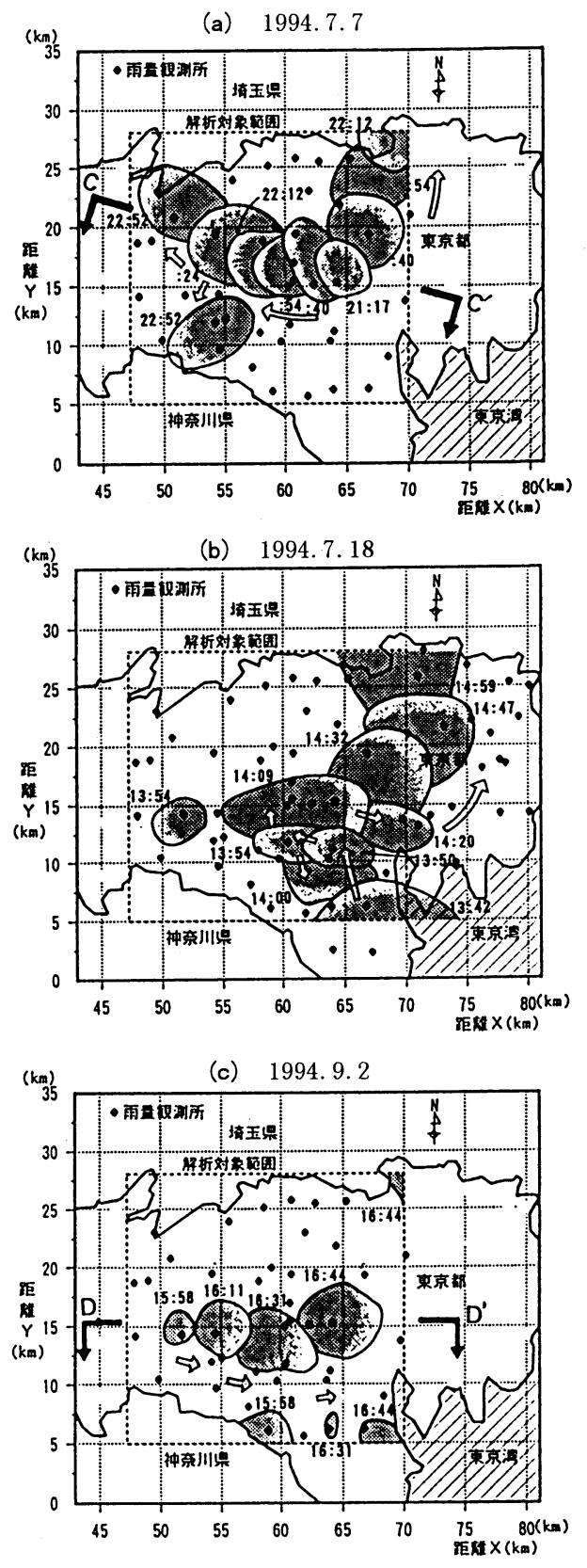

図-18 雷雨の発生状況

置が移動していくことで全体の雨域が動いている ことが明確にみられる.このひとつの雷雨による雨 量の発達, 減衰のサイクルは 12 分 17 分と平均的 に 15 分間であり，3〜 $5 \mathrm{~km}$ の間隔で連続して発生し ている. 図ー19に示される 1994.7.7 雷雨では, 図 -20 の様な個々の雷雨の発達・減衰を明確に分離 出来ない.これは, 観測所がうまく雷雨分布を把え きれていないためと考えられる。 

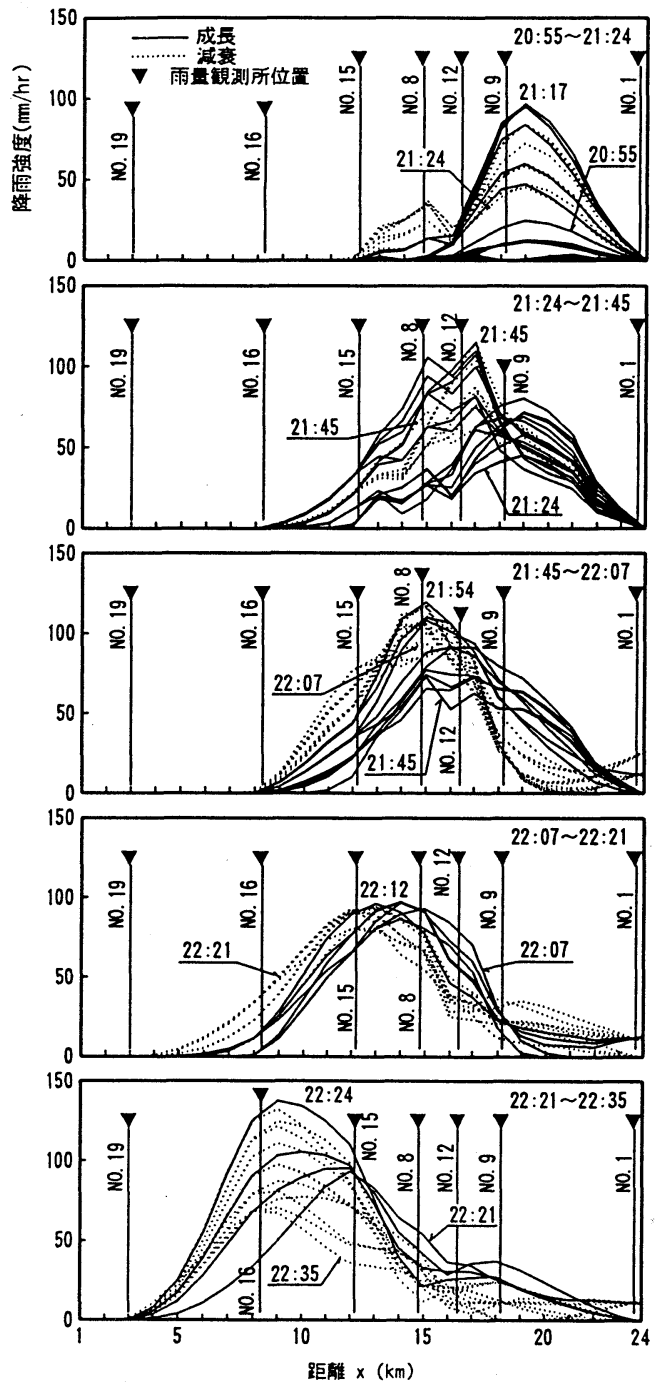

図－19 1994.7.7 雷雨のC断面雨量の経時変化

個々の雨量断面の成長と減衰をみると, それぞれ 5 〜10 分程度で変動している. これらの変動を精緻 に把えるには，10 分毎のデータでも粗く，困難で あると考えられる. 図一21 は, No. 12 観測所での観 測值と,変分法を用いて計算した格子点値（観測所 から 400m) の比較を示す. No. 12 観測所は, 図一 20 において雨量の発達・減衰を分けるところに位 置しており, 小さい雨量のときに若干周辺の観測所 の影響が現れているものの, ほぼ観測值と同様な值
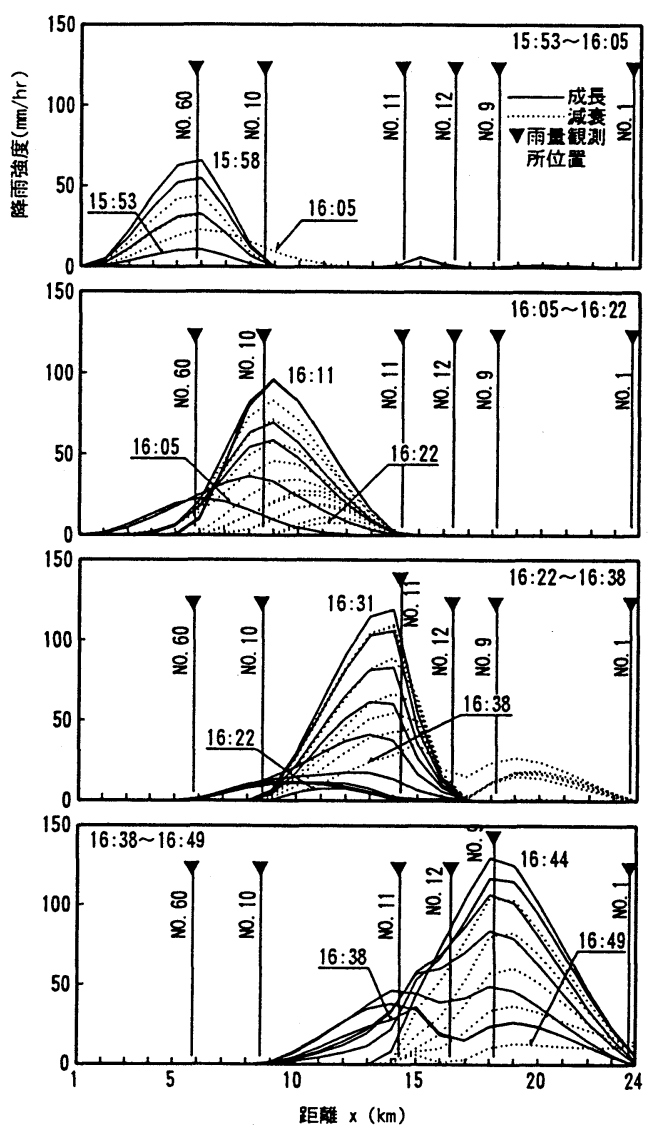

図－20 1994.9.2 雷雨のD断面雨量の経時変化

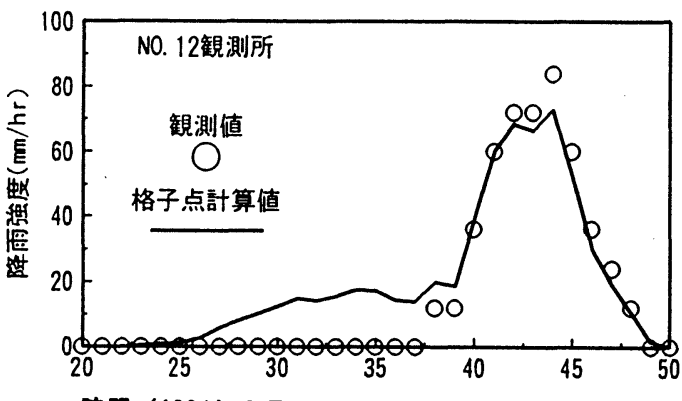

四（1994年 9 月 2 日 16時20分〜50分）（分）

図-21 観測值と格子点内挿值

で計算されている，このことから，図ー20に計算 で示された, 雷雨の時空間的な変動,つまり間欠的 に連続して発達・減衰する様子は, 各観測所の値を よく説明していると考えてよいであろう. 

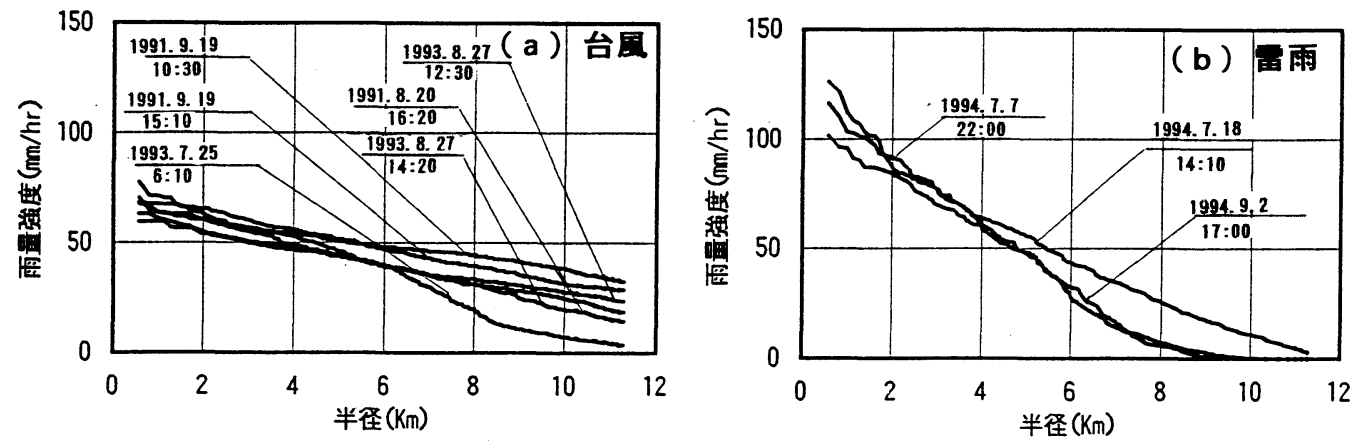

図-22 空間的雨量のひろがり（10 分雨量分布）
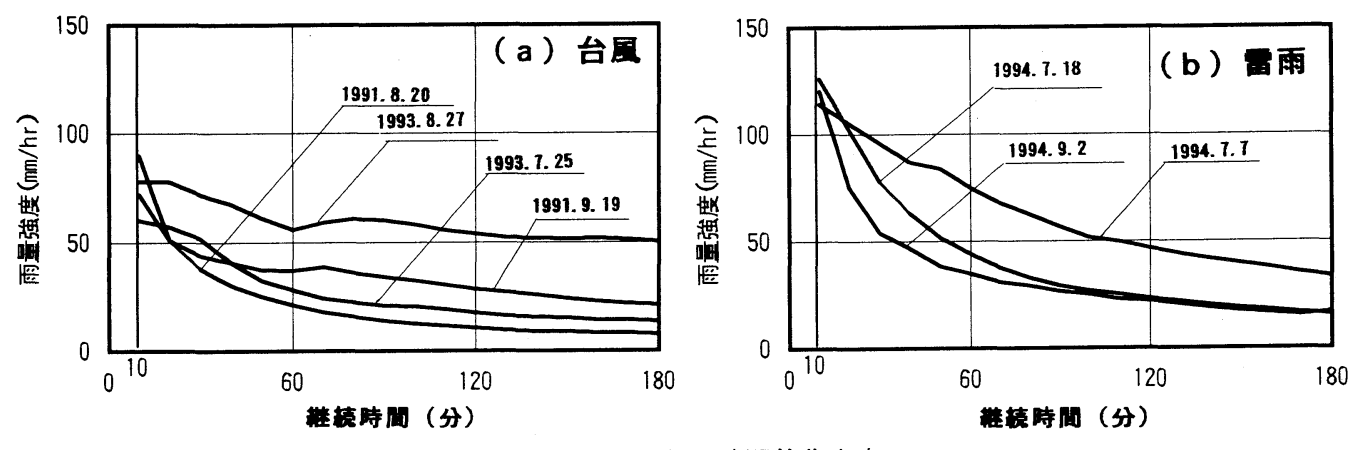

图一23 雨量の時間的集中度

\section{6. 短時間雨量の時空間分布特性}

\section{（1） 雨量の空間的なひろがり}

対象領域内の中央付近にピークを持つ雨量分布 の時刻を抽出し, その降雨の空間的なひろがりを調 べた. 雨量強度の面積的な低減を調べるため, 降雨 域の面積を円形の分布と仮定し,これを半径に換算 し雨量強度との関係を示したのが図ー22 である.

台風は $60 \sim 80 \mathrm{~mm} / \mathrm{hr}$ のピークに対し, $10 \mathrm{~km}$ 離れて も 20〜 40m $/ \mathrm{hr}$ 程度の雨量をもっており,さらに広 域に分布していると考えられる. 一方, 雷雨はピー クで $100 \sim 120 \mathrm{~mm} / \mathrm{hr}$ と大きいが, 中心から 8〜 $10 \mathrm{~km}$ 程度離れると雨域はなくなる. 雨量強度のピークに 対して $50 \%$ まで低減するのは, 雷雨で半径 $4 \sim 5 \mathrm{~km}$, また台風では半径 $6 \sim 8 \mathrm{~km}$ 程度の広がりをもつ. ま た, 雨域の移動速度が $20 \mathrm{~km} / \mathrm{hr}$ 程度 (30 分で $10 \mathrm{~km}$ の移動) とすれば, 観測点雨量は移動のみでもピー クから $50 \%$ 以下の雨量となる.このことから 30 分 程度の予測を行うにも雨量の分布形とその移動を 正確に捉えることが重要であることがわかる. 対象 領域が狭いため, 台風の分布の形状は明確ではない
が, 図ー16 の雨量分布図からみれば, 円形に近い場 合と帯状の分布をしている場合とがある様である. 雷雨の場合は図ー18 にみられるようなほぼ円形の 場合が多いが，時刻によっては近傍の 2 つの山の， 発達と減衰が重なったと考えられる双子形や長円 形の分布をしている. しかし，3〜 $5 \mathrm{~km}$ 間隔の観測 所の配置では, それ以上の細かさでの分布形状を把 えることは困難である.

\section{（2）時間的な集中度}

各降雨についてピークを示した降雨観測所の雨 量波形を抽出し, 継続時間と雨量強度の低減特性 （図一23）を調べた。台風性の降雨の場合は，10 分雨量のピークに比べ 60 分で $50 \sim 80 \%$ 程度の強度 まで低減する. 雷雨性の降雨では, 30〜 60\%程度ま で低減する. (b) 図に示す 1994.7.7 の雷雨はごく近 傍に次々に連続して発生しているため, 比較的時間 的な集中度が小さい. 台風の場合にはピークは小さ いものの, 1 山の場合には雷雨と同様の時間的集中 度をもっており，60〜120 分程度の複数の山が連続 することで大きな総雨量を記録している. 


\section{7. 短時間雨量の予測の可能性}

\section{（1）短時間雨量予測の方法}

本研究では, まず台風を対象として運動学的な手 法による短時間雨量予測の可能性を検討する.ラン ダムに配置される雨量計のデータから雨域の移動 方向を推定する方法として, 現時刻までの雨量デー 夕を対象として，前述した方法で雨域の移動・消長 を求め, 現時刻の雨量分布を時間的に外挿すること で 10 分〜 30 分先までの雨量を予測するものとした.

\section{（2）台風の短時間雨量予測の結果}

先述の対象とした 4 つの台風から抽出した 6 降 雨波形を対象として検討した。図一24に，対象領 域の中央付近に位置する N0.11 観測所の雨量観測 值と 10〜30 分先の移動のみによる予測と消長を加 えた場合の予測值を示す．6波形において，移動の みで良好に予測出来る場合，そうでない場合，消長 項を加えた方が移動のみによる予測より改善され る場合, 逆の場合, が明確に分けられた. 4 降雨の 6 波形のうち 3 波形 (図一24 中 (c)，(d)，(e)) では, 30 分予測においても雨量の立ち上がりの部 分が比較的良好に予測出来ている. 10 分後の予測 においては全ての降雨で, 消長を加える場合が良好 に予測出来た.これは, 雨域の移動や消長の継続性 が, 10 分程度まではあるが 30 分までいくと，その 継続性の仮定が破綻することによると考えられる. 10 分のリードタイムで, 移動のみで大きい誤差を もつ降雨は移動のみの予測値が観測值を予測時間 分遅らせただけとなっており, 消長の強い降雨, も しくは移動方向の変動が激しい降雨であったと考 えられる.これらの波形は 10 分のリードタイムに おいては消長項を加えることで修正が効くが，30 分のリードタイムとなると,さらに精度が劣ること になった. 図ー24中に図一17に対応する移動方向 や大きさの急変する時刻（印印）と消長が減衰から 成長へ大きく変化する時刻（山印）を記す. 特に, 雨量の立ち上がり時において, 雨域の移動や消長が 変化する場合においては, 30 分までの予測が極め て困難となっている.

\section{（3）雷雨の短時間予測に関して}

雷雨の変動は, 15 分程度で成長・減衰を繰り返 し, 連続して発生している.このことから，30 分
程度の予測はもとより, 10 分の予測でも, 運動学的 手法によることは極めて難しい. 雨域が次々に連続 し, 一定方向に発生していく場合には, その発生位 置はある程度推測出来る可能性はあるが, 移動・消 長の継続性が保たれると考えられる 5〜10 分以上 の, 降雨強度の定量的な予測は困難であると考えら れる.

\section{（4）予測精度向上の方策}

以上の降雨特性や降雨予測に関する知見から, そ の短時間降雨予測の精度を向上するための実際的 な方策を考察する.

\section{a) 対象領域の拡大}

本研究の $23 \mathrm{~km}$ 四方の領域では, 台風によるひと つの雨域の規模が $20 \mathrm{~km}$ 程度と仮定すれば，雨域の 発生からの消長・移動や分布形状の全容を把握し, 予測を行うには, 予測地点周りに $20 \mathrm{~km}$ 以上, 約 $50 \mathrm{~km}$ 四方程度の領域, 雨量観測所のネットワークが必要 であると考えられる。雨域の移動速度が 20〜 $30 \mathrm{~km} / \mathrm{hr}$ としても, 30 分で 10〜 15km 移動するためこ の程度の広さは必要である.

\section{b）細かな時間の雨量データ}

本研究で台風は, 10 分単位のデータにより移 動・消長を把えようとしたが，雨域のライフタイム が 60〜120 分とすれば, 10 分単位のデータでは降 雨波形の相関をとるにしてもデータのサンプル数 が少なく, 移動・消長の変動傾向を把えるには粗い と考えられる. また, 雷雨は 10～15 分毎の成長・ 減衰を繰り返すことも考慮すれば,ささらに細かい時 間間隔の雨量データを得ることで, 消長の周期性等 を考慮した精度良い予測を行える可能性はあると 考える.

\section{c）レーダ雨量の活用}

広域的な空間的に連続した雨量を把握する方法 としてレーダ雨量計がある. 狭域・短時間の雨量予 測に活用する場合には, 対象とする降雨が時空間的 な雨量の変動・分布のスケールが小さいことから, 地上の短時間雨量 (強度, $10 \sim 30$ 分雨量程度) と の相関を明らかにすることはもとより, 積雲スケー ルの時空間の解像度をもつ観測（例えば 5 分毎, $500 \mathrm{~m} \sim 1 \mathrm{~km}$ メッシュ等）と, 広域の平均的な移動傾 向のみでなく個々の積雲スケールの雨域の移動・消 長を考慮出来る予測手法の開発が必要と考えられ る. さらに, レーダ雨量が 5 分程度の間隔の瞬時值 
（a）時刻(1991年8月20日14時～17時)
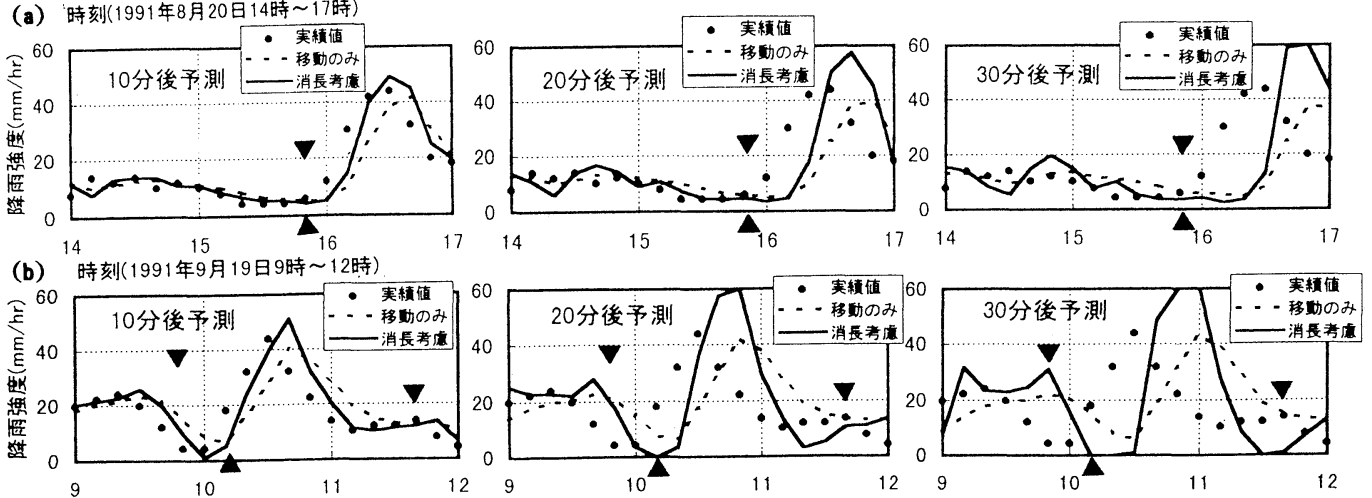

（c）時刻(1991年9月19日14時 17時)
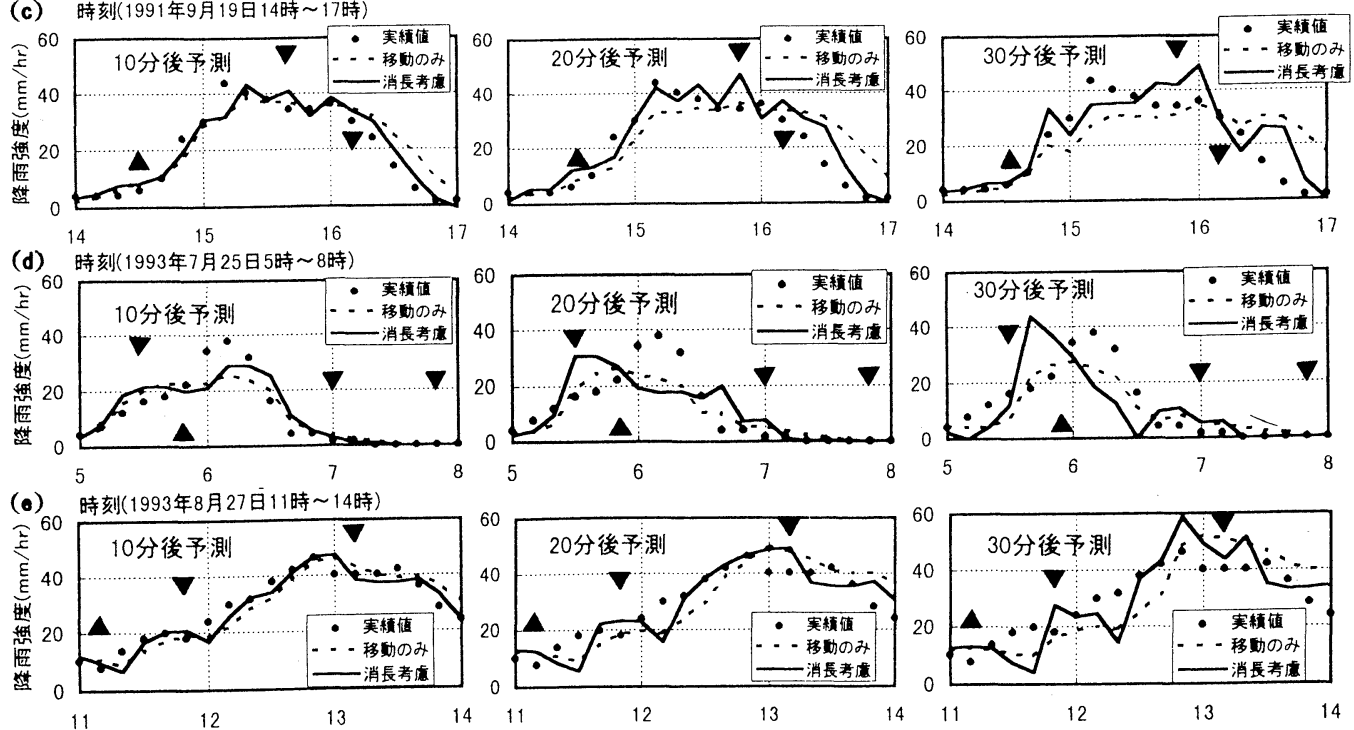

(f) 時刻(1993年8月27日14時 17時)
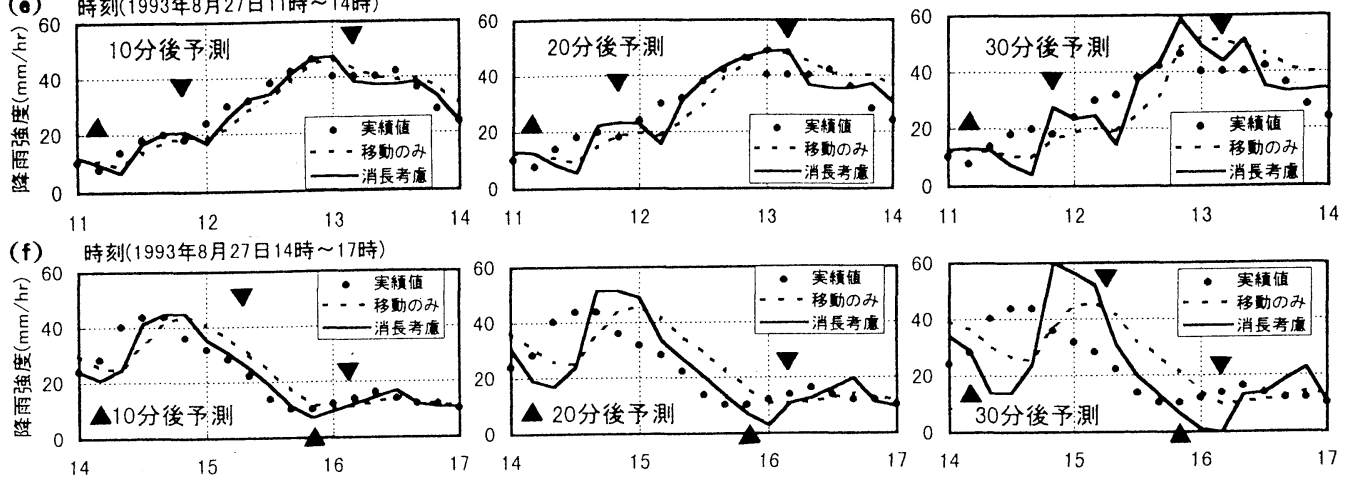

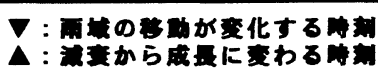

図－24 降雨予測結果

であることから, 地上雨量や流出との対応を考えた 平均化の方法と精度を考える必要がある.

\section{d) 気像学的, 統計的予測}

気象学的な諸元 (風, 温度, 湿度等) を観測し, 降雨の発生・変動・分布との対応を明らかにするこ とで, さらに予測精度を向上させる方法が考えられ る. 特に雷雨等は, その発生からの予測が必要であ り, 3 次元的な雨量や気象要素の細かな観測手法と. メソ $y$ スケールの気象力学的解析手法の確立が, 不 可欠であると考えられる. 一方, 雷雨や台風等の降
雨要因毎の変動や分布の統計的な特性を把握する ことにより，その予測への適用や，都市域中小河川 流域規模の計画, 管理に反映することも必要である と考えている.

\section{8. 結 論}

本研究では, 密な地上雨量計データをもとにして, 都市中小河川流域規模 $\left(10 \sim 100 \mathrm{~km}^{2}\right.$ オーダ $)$ の短時 間雨量 (5〜30 分程度) について, そのダイナミッ 
クな変動と分布の特性を検討した. その主要な結論 を以下に示す.

（1）台風による短時間（30 分）雨量は, 雷雨と比 較すれば平坦な分布をしているが, そのピークから 6〜 $8 \mathrm{~km}$ で $50 \%$ 程度にまで低减する．ひとつの雨域 は，対象領域とした $23 \mathrm{~km}$ 四方では把えきれない広 がりをもつ. 狭い領域での雨域の移動や消長は，本 研究の方法でほぼ推定出来る.その移動は雨量の大 きい範囲で空間的・時間的にほぼ一様である、移動 が卓越する場合と, 移動が殆どなく, 発達, 減衰す る場合がみられた，移動の速さは速い場合でも $20 \mathrm{~km} / \mathrm{hr}$ 程度のオーダであると考えられ，運動学的 方法で 30 分 60 分の降雨予測を行うには, $10 \mathrm{~km} \sim$ $20 \mathrm{~km}$ 雨域が移動するため, 本研究の対象範囲より さらに広い, 降雨観測網が必要となる.また，変動 の周期性が 60〜120 分であることを考えれば，10 分単位よりさらに細かい時間間隔のデータを得る ことで予測精度の向上は図れると考えられる.今後 は, 広域的かつ空間的に連続したデータが得られる レーダ雨量と, 中小河川の流出との応答が極めて高 く, 時間的に連続した地上雨量との連携を考えてい く必要がある。

（2）雷雨は, 約 $10 \mathrm{~km}$ のひろがりを有し, 集中度の 高い雨量が, 15 分程度で発達・減衰し, その近傍 3 ～ $5 \mathrm{~km}$ 間隔でほぼ一方向に次々に連続して発生す る. 現在の $3 \sim 5 \mathrm{~km}$ 間隔の観測所配置・密度でも 細かに雷雨の分布を把えきれないためと考えられ るが, 個々の雷雨の発達, 減衰を明確に分離・把握 出来ない場合もある. 雨域は全体として一様な方向 に連続して発生する傾向があるが，2 方向に分かれ て発生する場合や迷走する場合もみられる.雷雨の 時空間的な変動を精緻に把えるにはさらに時空間 的に細密な情報が必要であり，その発生や変動を予 測するには, 1〜5 分オーダ, $500 \mathrm{~m} \sim 1 \mathrm{~km}$ スケール の雨量観測, 地上雨量とレーダ雨量の各々の特徵を あわせた観測方法や気象的な観測, 解析が必要と考 えられる. 狭小域では, 雷雨は約 1 時間で発生消滅 するため, $1 \sim 3$ 時間先の予測を行うには, 気象学 的な要素を取り込んだ解析が不可欠であると考え られる。

（3）雨量の短時間予測についてその可能性を検討 した. 台風の, 10 分先の予測については, 移動や 消長の継続性が保たれるため, 運動学的方法である 程度良好に予測の行えることを示した．30 分まで
のリードタイムとなると, 移動や消長の変動が安定 している場合には, 予測が良好に行えるが, 降雨量 の立ち上がり部で, 移動もしくは消長が急変する場 合もあり, 予測は極めて困難となる. メソ $\alpha$ スケー ルの現象といわれる台風 ${ }^{22)}$ では, その進路等の予 測はかなりの精度で行われる様になってきている が, 中小河川流域規模では, 台風といえどもその内 部のさらに小さい個々の積雲スケールでの雨域の 移動・消長が重要となるため, $1 \sim 3$ 時間先の定量 的な雨量予測は困難である. また, 雷雨については, 極めて地域的な集中度と時間的な変動が激しいた め, 台風に比して, 運動学的な方法では, 30 分先 の定量的な雨量予測は困難であることが明らかで あり，予測精度向上の方策を考察した。

本研究では, 都市中小河川の流出と相関の高い密 な地上雨量を対象としてその特性を明らかにした. 対象とした時空間スケールでの降雨量は, 特に雷雨 で極めて集中度の高く変動の激しい特性を示した. 狭小流域, 特に都市中小河川での流出現象はこれら の短時間降雨の特性と密接に関連しているため, 密 な精度よい雨量観測を行い解析していくことが重 要である. 今後, 降雨観測, 予測を行っていく上で 短時間雨量の変動, 分布特性を考慮し, 地上雨量と レーダ雨量との各々のメリットを生かした連携方 法を考えていくことが重要と考える. また, 都市中 小河川の管理や水防活動を適切に行うための降雨 の観測，予測や流出計算を行うには，これらの短時 間雨量の変動・分布特性を反映した方法とその精度 の限界, 流出との対応を見極めていくことが重要で ある.

\section{参考文献}

1）東京都建設局河川部計画課 : '85 東京の中小河川, p. 5 , pp. 22-24, p. 26, 1985.

2）西澤賢二:都市河川の技術，大村書店, pp. 123-125, 1976.

3）建設省河川局監修，社団法人日本河川協会編 : 改訂建設省 砂防技術基準（案）計画編，pp. 19-20, 同調査編, pp. 149-150, 山海堂, 1985.

4）建設省土木技術研究所水文研究室 : 関東南部D AD調査報 告，土木研究所資料，第 1187 号，1977.

5）吉野文雄，水野雅光，井川貴史 : レーダ雨量計から見た降 雨の時空間特性について, 土木学会第 32 回水理講演会論 文集, pp. 1-6, 1988.

6）建設省土木研究所河川部水文研究室 : レーダ雨量計から見 た降雨の時空間特性に関する調查報告書, 土木研究所資料 
第 2604 号, 1988.

7）渡邊茂, 高棹㙇馬, 椎葉充晴, 及川隆仁, 小寺寿充 : レー ダ雨量計デー夕を用いた降雨場の時間的・空間的特性の解 析, 土木学会第 46 回年次学術講演会概要集 (II), pp. 42-43, 1991.

8）小林明, 小笠原智宏, 松崎実, 山口高志, 大塚俊匡 : レー ダ雨量の時間外挿キャリブレーション手法の検討，第 33 回水理講演会論文集, pp. 97-102，1989.

9）中村興一, 堀田哲夫, 山下芳治, 星清 : レーダ雨量計精度 向上への Kriging 法の活用, 水工学論文集, 第 36 巻, pp. 489-494, 1992.

10）竹村公太郎，西原巧，三日市吉郎，石原篤，村尾浩太，小 島富士夫, 吉元隆明 : レーダデータの実時間補正法に関す る研究, 第4 回河川情報センター研究発表会講演集, 財団 法人河川情報センター, pp. 31-37，1995.

11）神野健二, 河村明, 西山浩司, 脇水健次, 古川節 : レーダ 定数の特性および地上雨量のオンライン予測に関する研 究, 平成 6 年度河川情報センター助成研究成果報告集, 財 団法人河川情報センター, pp. 27-35, 1995.

12) 河村明, 神野健二, Janusz Niemczynowicz, Ronny Berndtsson, Magnus Larson : 短時間都市規模地上降雨の 時空間特性と実時間予測について, 水工学論文集, 第 35 巻, pp. 63-68, 1991.

13）沖大幹, 虫明功臣: 雨滴粒径分布観測による短時間降雨強 度の変動特性, 水工学論文集, 第 38 巻, pp. 33-38, 1994.

14）友杉邦雄 : 面積雨量の推算值の信頼性に関する研究一長崎 豪雨における雨量の空間的変動性と可能誤差の特性一, 京 都大学防災研究所年報, 第 27 号 B- 2, pp. 221-232, 1984.

15）中津川誠: 流域スケールの降雨特性の研究, 北海道開発局 開発土木研究所環境研究室報文, pp. 209-218, 1990.

16）山田正, 藤田睦博, 茂木正, 中津川誠 : 山地流域における 降雨観測と降雨の特性について, 水工学論文集, 第 34 巻, pp. 85-90, 1990.

17）山田正, 茂木正, 亀田祐二 : 山地流域における降雨の分布 特性と降雨の数值シミュレーション, 水工学論文集, 第 35 巻, pp. 243-250, 1991.

18）建設省編:建設白書 (平成 7 年版), 大蔵省印刷局, p. $361, p$. 資 $32,1995$.
19）谷岡康, 福岡捷二 岩永勉, 北川明: 都市域中小河川にお ける洪水位と雨量の直接的関係を用いた洪水解析, 水工 学論文集, 第 38 巻, pp. 69-74, 1994.

20）福棡捷二 谷岡康, 高本正彦: 都市中小河川流域における 雨量観測所密度が面積雨量精度に与える影響, 水工学論 文集, 第 37 巻, pp. 27-32, 1993.

21）谷岡康, 伊藤重文, 渡边毅, 福岡捷二, 高本正彦 : 神田川 流域に扔引る面積雨量精度, 第 48 回年次学術講演会講演 概要集第2部, pp. 144-145, 1993.

22）朝倉正, 関口理郎, 新田尚 : 気象ハンドブック, 朝倉書店, pp. 133-134, 1995.

23）谷岡康, 福岡捷二, 岩永勉, 傅雲飛 : 都市中小河川流域規 模を対象とした短時間雨量の変動特性と短時間降雨予測 の試み, 水工学論文集, 第 39 巻, pp. 55-60, 1995.

24）谷岡康, 福岡捷二, 傅雲飛, 岩永勉: 都市中小河川流域規 模を対象とした短時間降雨予測の試み，土木学会第50回 年次学術講演会概要集第 2 部 (A), pp. 34-35, 1995.

25）谷岡康, 福棡捷二, 傅雲飛 : 都市中小河川流域規模を対象 とした地上雨量計による短時間雨量の変動予測, 水工学論 文集, 第 40 巻, pp. 273-278, 1996.

26）大倉博，石崎勝義，中尾宏臣，森本陸世 : レー夕゙雨量計を 用いた短時間降雨予測，第 27 回水理講演会論文集， pp. 349-354, 1983.

27）椎葉充晴, 高棹琢馬, 中北英一 : 移流モデルによる短時間 降雨予測手法の検討, 第 28 回水理講演会論文集, pp. 423-428, 1984.

28）財団法人日本気象協会 : 防㷋システム (主に集中豪雨等) の開発一集中豪雨の実況監視，予測および各種災害予知の 表示システムの開発一, pp.4-10, 1987.

29）山崎真一，増田禁隆，新庄興 : 石狩川の降雨特性に関寸る 研究，第 33 回北海道開発局技術研究発表会, pp. 227-232, 1989.

30）伊藤繁之, 福剛捷二, 谷岡康 : 都市中小河川流域における 雷雨性降雨の時空間変動特性, 土木学会第 51 回年次学術 講演会講演概要集 第2 部 pp. 168-169, 1996.

31）二宮洸三:雨とメソ・システム, 気象学のプロムナード 2 , p. 189, 東京堂出版, 1989.

（1996. 12.17 受付）

\title{
A STUDY OF CHARACTERISTICS OF SHORT-TERM RAINFALLS IN SMALL URBAN RIVER BASINS
}

\author{
Yasushi TANIOKA, Shoji FUKUOKA, Shigeyuki ITO, Yukiya KOYAMA \\ and Yunfei FU
}

\begin{abstract}
For adequate river management, flood fighting and flood control in urban small river basins, it is important to understand the characteristics of short time rainfalls in small catchments, including rainfall's migration, their rise and declime, as well as the time-space distribution. Concentrated shorttime thunderstorms and widespread longtime rainfalls of typhoons are the main cause of flooding in urban small river basins. In this study, the characteristics of short time, 5-30 minutes rainfalls within 23 square $\mathrm{km}$ area of thunderstorms and typhoons are studied based on the densely-observed data from the gauging station network in Tokyo. The possibility of short-term rainfall prediction is considered from the analysis of these characteristics.
\end{abstract}

